\title{
The Mowat Boat and the Development of Small Watercraft on the Great Lakes
}

\begin{abstract}
John E. Ratcliffe
De 2003 à 2007, une équipe de volontaires au Musée Maritime des Grands Lacs, à Kingston dans l'Ontario, a rénové un bateau en bois de 28 pieds qui était une fois la propriété de Angus Mowat, père de l'auteur Farley Mowat. Cet article est basé sur une étude de l'histoire du bateau entreprise pour compléter le travail de restauration. La recherche archivistique a indiqué qu'à l'origine le bateau a été construit comme bateau de pêche à la voile aux alentours de 1910 avant d'être convertie en bateau de pêche motorisé, et plus tard yacht. Dans ces diverses incarnations le " bateau de Mowat" a incorporé des éléments importants dans l'histoire de ce type de bateau des Grands Lacs antidatant de beaucoup la première construction de celui-ci. Ces éléments conceptuels fournissent à leur donnent un aperçu sur d'autres points d'intérêt dans l'histoire maritime des Grands Lacs.
\end{abstract}

\section{Introduction}

In 1989 the Marine Museum of the Great Lakes in Kingston, Ontario acquired the dilapidated shell of a 28-foot wooden boat. The hull lay on the grass outside the museum, and it was difficult to imagine it had once been a fine sailing craft, painted in a rakish red and black colour scheme. The paint was peeling off her mostly rotten timbers, and leaves and debris littered her bilges. The boat languished outside for over ten years before a group of enthusiastic volunteers took a second look and decided to restore her.

Research undertaken before restoration work began soon revealed that this vessel had an unusual story to tell. She was built by a local fisherman around 1910 and was one of the last of the great fleet of sailing fishing boats on Lake Ontario. A half-century after that her mast was removed and she was fitted with a cantankerous gas engine, in order to continue earning her keep fishing on the lake. Later she was purchased by Angus Mowat who had seen her being built in his youth. As a retirement project he fixed her up as a yacht, extensively altering the boat's structure in the process. Mowat was by then perhaps best known for his famous son, the celebrated author Farley Mowat, and thus the boat, which had known many names in her long life, became known as "The Mowat Boat."

The saga of the Mowat Boat, from sailing fishing boat to motor fishing boat to yacht to museum piece closely parallels wider trends in the development of small watercraft in the entire Great Lakes region. An exploration of the various incarnations of 
the Mowat Boat provides a good perfect framework within which to study the types, history, and evolution of small watercraft on the Great Lakes, as well as more theoretical issues of restoration philosophy.

\section{Mowat Boat Influences - Mackinaw Boats}

In the mid-nineteenth century a new type of fishing boat began to be noticed in the western Great Lakes, around the Straits of Mackinac in Lake Michigan and Manitoulin Island in Lake Huron. These boats' salient characteristics are admirably summarized by Rodger Swanson, who drew on the works of James Barry: "A doubleender of 18-30' plus in length, plumb stemmed, marked rake to sternpost, half decked, two masts (usually gaff ketch), round bottomed, fitted with a centerboard, and sporting a jib set ona hogged bowsprit. Planked, either lapstrake or carvel. Original waters of use the Upper Great Lakes. Often associated with the Straits of Mackinac. Certain specific variations associated with time and place."

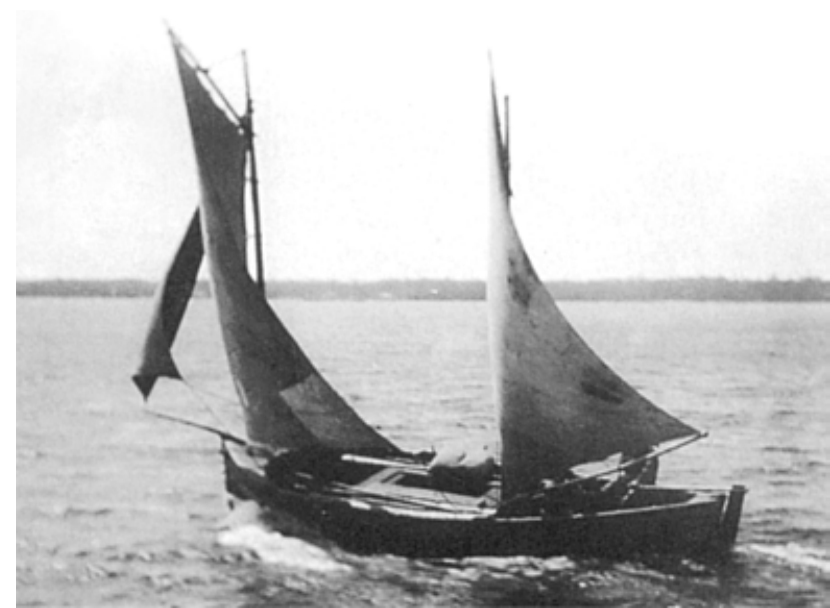

Figure 1: A typical ketch-rigged Mackinaw boat of Lake Michigan. The widest beam is forward of amidships and the stern is very fine, contributing to the distinctive "cod's head and mackerel's tail" shape. Courtesy WoodenBoat and Owen S. Cecil.
These double-ended fishing boats (figure 1) eventually came to be called "Mackinaw boats," based on their reputed place of origin. Mackinaw boats are extremely important for the study of the small watercraft of the Great Lakes, since they were one of the most common and recognizable types of boat in the latter half of the nineteenth century, and enjoyed a wide geographic distribution. ${ }^{2}$ The Mowat Boat has sometimes been compared to a Mackinaw boat, ${ }^{3}$ and the two types are of a similar length, and are both double-ended, with round bilges, partial decking, and a centreboard. A closer examination of the form and characteristics of Mackinaw boats, however, reveals a boat that is substantially different from the Mowat boat, despite some superficial resemblance.

In the 1840s Jesuit missionaries among the native peoples of northern Michigan and Manitoulin Island must have felt they were finally making progress in convincing the

1 Rodger C. Swanson and Edith Jane, “A Search for the Real Mackinaw," WoodenBoat No. 45 (1982), 100.

2 A.B. McCullough, The Commercial Fishery of the Canadian Great Lakes (Hull, QC: Environment Canada 1989|), 41.

3 Tom Jackson, “The Black Angus Restoration,” WoodenBoat No. 193 (2006), 20-21; also some of the Mowat Boat restoration team themselves, November 2007. 
natives to abandon their traditional culture in favour of the "civilized" ways of Western society. It seems the natives had replaced their canoes with wooden sailing boats, of the kind later to become famous as Mackinaw boats. At the Algonqian reservation of Wikwemikong on Manitoulin Island there were 86 boats for a population of only 822 people in $1857 .{ }^{4}$ These native boats had a very distinctive hull shape, described as a "cod's head and mackerel's tail." In this form the fullest part of the boat is forward of amidships (the "cod's head") while the stern tapers to a very fine end (the "mackerel's tail"). This shape is especially noticeable in the lines of the Wabesi of 1845, shown in figure 2 .

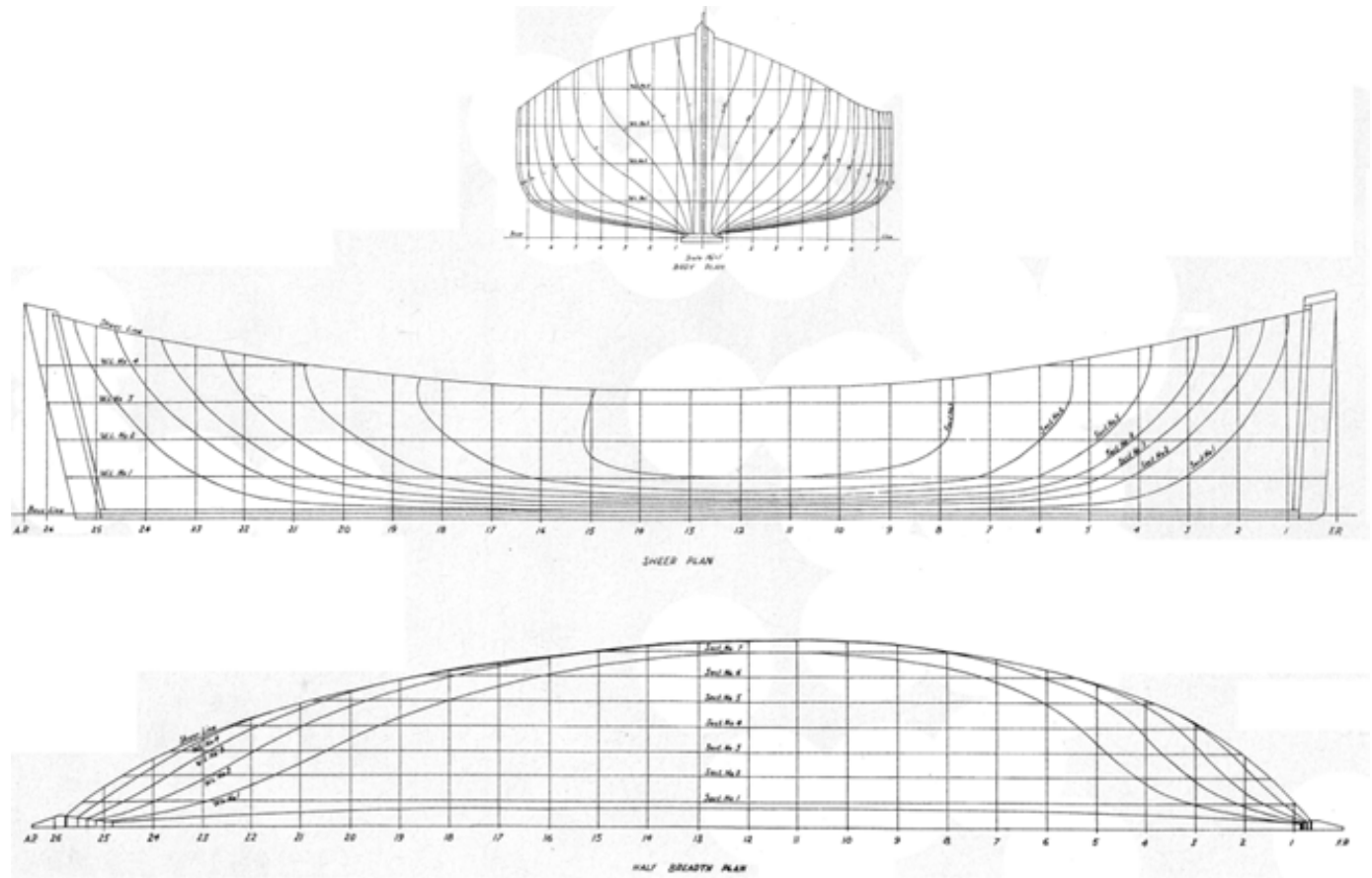

Figure 2: The lines of the Wabesi, built c. 1845 show the "cod's head and mackerel's tail" shape that characterize "true" Mackinaw boats. In this shape the fullest part of the boat is well forward of midships, while the stern tapers to a fine end. Courtesy WoodenBoat and Owen S. Cecil.

The Wabesi was built about 1845 by Hyacinth Chenier, a French-Canadian boatbuilder, who along with the Algonqians of the western lakes is often credited with "inventing" the Mackinaw boat. In the 1830s Chenier moved from near what is now Oka, Quebec to St. Ignace, Michigan, on the north side of the Straits of Mackinac. He was listed as a boatbuilder in the 1850 census, a craft he continued to practice until his death in 1893. Chenier did not leave any records as to the inspiration or origins of his designs, but it is entirely probable that he adopted and improved upon the boatbuilding practices developed among the natives in the area by the time he arrived. St. Ignace is only about 240 kilometres from Manitoulin Island, one of the places where the Mackinaw boats

4 Owen S. Cecil, “The Mackinaw Boat,” WoodenBoat No. 158 (2001), 65-66.

5 Cecil 2001, 68. 
originated. There had always been a sympathetic link between the French and native cultures, a link no doubt strengthened by Chenier's marriage to a local Métis woman in 1841.6

Although the double-ended fishing boats used around the Straits of Mackinac and Manitoulin Island, and later further afield, came to be called "Mackinaw boats," it seems this term is a later invention used for reasons of convenience and marketing, or through simple ignorance. A storekeeper on Manitoulin Island, when asked by a researcher if he remembered any "Mackinaw boats," replied "We just called them Indian sailboats. They didn't have a name... At one time or another, they called anything a Mackinaw boat." When fishing boats began to be converted to yachts in the last quarter of the nineteenth century, they were often given more attractive names to boost sales and aid in marketing. Thus the prosaic "Maine sloop boat" became the more amicable "Friendship sloop," and the double-ended fishing boats of the western lakes that were known simply as "fish boats" or "Indian sailboats" were irrevocably re-labelled as "Mackinaw boats." 8 While it is useful to be able to associate a certain type of boat with a specific name, nomenclature and typology should not become ends unto themselves. As boat researcher Eric McKee remarked: "It is simpler to stop trying to read meanings into boats' names...[they] can never be the basis of a classification system."

\section{Characteristics of Mackinaw Boats}

Even so, many have tried to isolate specific features of western lakes fishing boats and so define a "true" Mackinaw boat. One of the first to make this attempt was Joseph Collins, working for the United States Fish Commission in 1887 at a time when Mackinaw boats were at the apogee of their popularity. Collins defined Mackinaw boats as double-ended open boats with a centerboard and a noticeable sheer. The ends were sharp, the midships section was "bulging," and the stern was "remarkably fine." The planking of the boats could be either carvel (edge-to-edge) or lapstrake (overlapping edges), and most boats were two-masted. They were rigged like a schooner with a loosefooted gaff-foresail and gaff mainsail, as well as jib sail attached to the bowsprit. The average length of the boats in northern Lake Michigan at the time was about 26 feet. $^{10}$

This description sounds remarkably like the aforementioned Wabesi, which is one of the best primary sources of evidence about Mackinaw boats. After Chevrier built the Wabesi c. 1845 it was owned by a native fisherman named Joseph Osogwin for about 70 years until his death around 1915. Luckily for posterity, a small craft enthusiast named Oliver Birge recorded her lines and dimensions in 1933. Wabesi had a length overall (LOA) of 26 feet and a maximum breadth of 7 feet, 6 inches. She was sparred as a

\footnotetext{
6 Cecil 2001, 65.

7 Cecil 2001, 63.

8 Lorne Joyce, "Fish Boats Under Sail," Inland Seas Vol. 53, No. 1 (1997), 12.

9 Eric McKee, Working Boats of Britain: Their Shape and Purpose (London: Conway Maritime Press, 1983), 80.

10 Cecil 2001, 64.
} 
schooner, with a 27-foot mainmast and 24-foot foremast carrying a gaff rig, and a jib that could be secured to a removable bowsprit. ${ }^{11}$ While called a schooner rig by the fishermen at the time, it would be considered a ketch rig in modern parlance. ${ }^{12}$ The hull was carvelbuilt with pine planks, and the cedar frames or ribs were cut from naturally formed tree crooks, a method favoured by First Nations builders that added strength. The shape of the Wabesi's hull closely conforms to Collins' later description of Mackinaws. She is doubleended, with a plumb (vertical) stem and raked stern, with full bows and midship section which tapers to a fine, narrow stern. Wabesi means "swan" in the local Ojibway dialect, and the name is a most likely a reference to her white hull and sails. ${ }^{13}$

Mackinaw boats were primarily used for fishing, and their design was functional. The sharp stern meant that the boat could easily move backwards through the water as nets were hauled in, while the partial decking and cockpit coaming helped keep the waves out, allowing the boats to ride out rough weather. The fore-and-aft gaff rig on two masts provided about 500 to 550 square feet of sail which resulted in a craft that was generally speedy, except when heading to windward. The fore-and-aft rig could be handled by only two men and thus minimized labour costs and the division of profits. ${ }^{14}$ However, by modern standards Mackinaw boats could be considered somewhat dangerous. Open boats are inherently more prone to swamping in heavy swells than decked ones. Mackinaw boats were ballasted with about one ton of weight, usually consisting of beach boulders. These stones could slide around, or alternatively freeze in place late in the season. The ballast would be moved to the windward side when underway, and crew members also acted as a form of moveable ballast. Mackinaws had a relatively large sail area for their size, which when combined with the unsecured ballast and small number of crew members increased the risk of capsizing in conditions as commonplace as a sudden summer squall. ${ }^{15}$ However, it should be noted that the definition of a "safe" or "seaworthy" boat is relative. The users of Mackinaw fishing boats were professionals; they earned their living using their boats in a full-time, albeit seasonal, occupation. These men and women had a detailed and intimate knowledge of local conditions as well as the handling characteristics and limitations of their boats.

\section{Relation of Mackinaw Boats to the Mowat Boat}

While it has already been acknowledged that the Mowat Boat bears some superficial resemblance to Mackinaw boats, Table 1, below, provides a more empirical basis for comparison. The data on the Mowat Boat is derived from a set of lines prepared by the boat researcher Phillip Gillesse, while that for "Mackinaw boats nos. 1-4" is taken from volume V of the Historic American Merchant Marine Survey (HAMMS). This latter work was a pioneering effort to record a wide variety of American sailing vessels before they were lost. There are, however, a number of inconsistencies and errors in the

\footnotetext{
11 Swanson 1982, 102.

12 Joyce 1997, 6.

13 Swanson 1982, 102.

14 Joyce 1997, 4-6.

15 Joyce 1997, 8, 10.
} 
HAMMS drawings; HAMMS was conceived as a "make-work" project in the 1930s, which resulted in staff of varying backgrounds and levels of experience. ${ }^{16}$ Thus the data

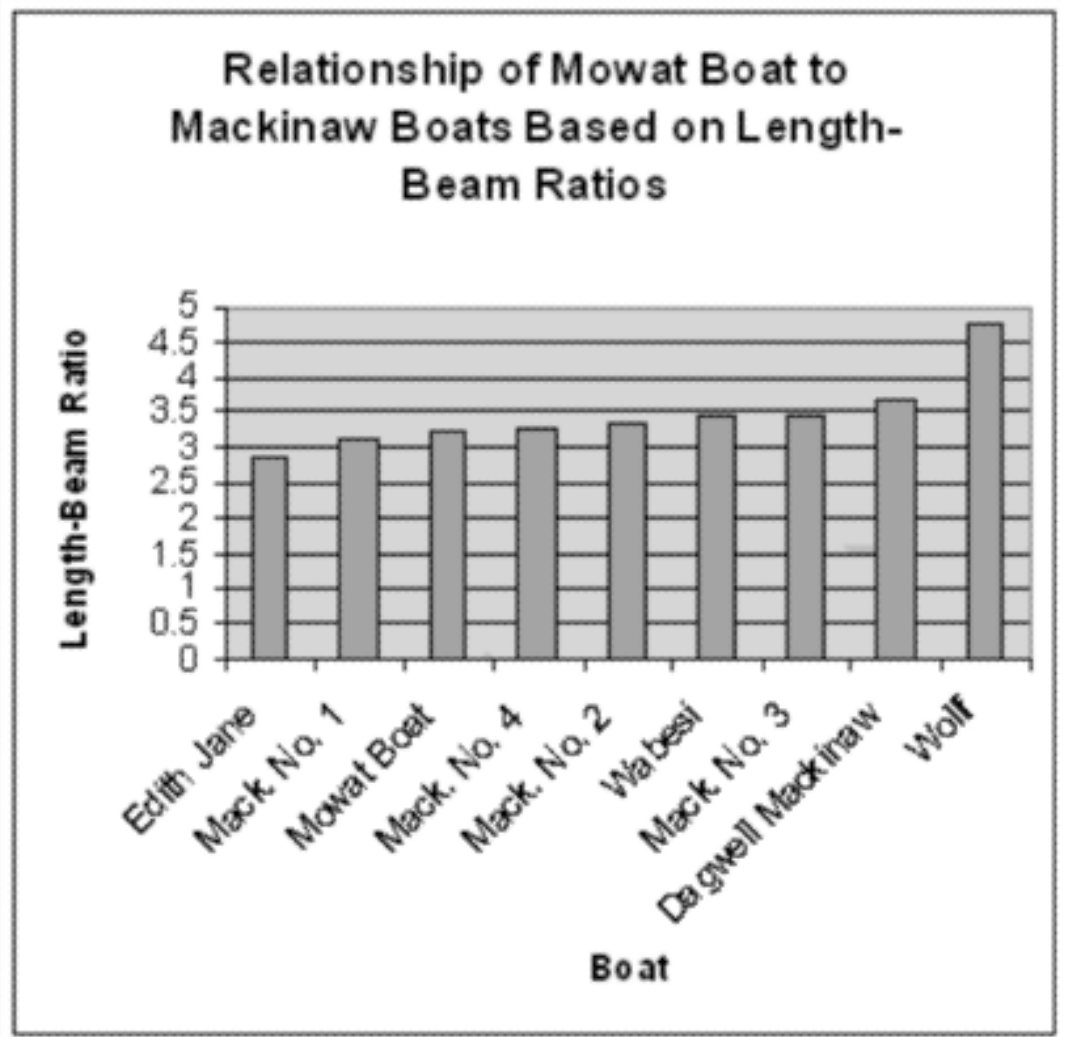

Graph 1. The length-beam relationship of eight Mackinaw boats to the Mowat Boat is more easily understood graphically, where the Mowat Boat is one of the beamier boats.

from HAMMS must be used with caution. The dimensions for the Mackinaw boats Edith Jane, Wabesi, Wolf, and the Mackinaw built by Charles Dagwell are taken from Rodger Swanson's invaluable 1982 article from WoodenBoat. The dimensions compared are length overall (LOA) and maximum beam (B-Max). When the former is divided by the latter it results in the length-beam ratio (L/B Ratio), a useful tool for comparing different craft.

\begin{tabular}{|l|l|l|l|l|l|l|}
\hline Name & Year Built & Place & LOA & BOA & L/B Ratio & Class \\
\hline Mowat Boat & 1910 & $\begin{array}{l}\text { Near Trenton, } \\
\text { ON }\end{array}$ & $27^{\prime} 4^{\prime \prime}$ & $8^{\prime} 5^{\prime}$ & 3.25 & Normal \\
\hline Mack. No. 1 & 1887 & $\begin{array}{l}\text { Charlevoix, } \\
\text { MI }\end{array}$ & $28^{\prime}$ & $9^{\prime}$ & 3.11 & Normal \\
\hline
\end{tabular}

16 David A.Walker, "Historic American Merchant Marine Survey: Volume V. Notes on the accuracy of the material," in The Great Lakes Historic Ship Research Project (Kingston, ON: Marine Museum of the Great Lakes, 1989), 68-9. 


\begin{tabular}{|l|l|l|l|l|l|l|}
\hline Mack. No. 2 & 1900 & $\begin{array}{l}\text { Charlevoix, } \\
\text { MI }\end{array}$ & $34^{\prime} 6^{\prime \prime}$ & $10^{\prime} 3^{\prime \prime}$ & 3.36 & Normal \\
\hline Mack. No. 3 & Unknown & $\begin{array}{l}\text { Drummond } \\
\text { Is., MI }\end{array}$ & $28^{\prime} 9^{\prime \prime}$ & $8^{\prime} 3^{\prime \prime}$ & 3.48 & Normal \\
\hline Mack. No. 4 & 1900 & $\begin{array}{l}\text { Charlevoix, } \\
\text { MI }\end{array}$ & $33^{\prime}$ & $10^{\prime}$ & 3.30 & Normal \\
\hline Edith Jane & 1899 & $\begin{array}{l}\text { St. Ignace, } \\
\text { MI }\end{array}$ & $18^{\prime}$ & $6^{\prime} 4^{\prime \prime}$ & 2.84 & Normal \\
\hline $\begin{array}{l}\text { Dagwell } \\
\text { Mackinaw }\end{array}$ & 1900 & $\begin{array}{l}\text { Mackinac } \\
\text { City, MI }\end{array}$ & $16^{\prime}$ & $4^{\prime} 4^{\prime \prime}$ & 3.69 & Normal \\
\hline Wabesi & 1845 & $\begin{array}{l}\text { St. Ignace, } \\
\text { MI 26' }\end{array}$ & $7^{\prime} 6^{\prime \prime}$ & 3.46 & Normal \\
\hline Wolf & 1864 & $\begin{array}{l}\text { Gem Island, } \\
\text { MI }\end{array}$ & $44^{\prime}$ & $9^{\prime} 33^{\prime \prime}$ & 4.75 & Narrow \\
\hline
\end{tabular}

Table 1. The dimensions of various Mackinaw boats compared to the Mowat Boat.

Based on McKee, a Length-Beam ratio of 2.6 or under will be considered "beamy," while a quotient of 3.75 or over will indicate a "narrow" boat, ${ }^{17}$ with the values in between those limits defined as "normal."

The length-beam ratios of eight Mackinaw boats and the Mowat Boat in Table 1 do not seem particularly enlightening, as eight of the nine are classed as "normal," while only the unusually large Wolf from 1864 is considered "narrow." When those same values are expressed graphically more insight is gained into the relationship between the various small watercraft. In Graph 1 the length-beam ratios of the watercraft are displayed in ascending order. The Edith Jane, with a L/B ratio of 2.84 , is the closest to a "beamy" boat.

Although the Mowat Boat falls within the "normal" range, its position indicates that it is a beamier boat than most of the Mackinaws.

A comparison of the lines of the Mowat Boat, figure 3 on the following pages, with those of Mackinaws such as the Wabesi, Edith Jane and Dagwell's Boat, reveals that the Mowat Boat has a much more symmetrical shape and lacks the characteristic cod's head and mackerel's tail shape. Furthermore, the Mowat Boat was only ever equipped with a single mast, while the vast majority of Mackinaw boats were rigged with two masts. The Mowat Boat certainly has some similarities to a Mackinaw boat, but to give it such a name would be a misnomer.

\section{Mowat Boat Influences- The Collingwood Skiff}

The Mowat Boat has also been compared to a type of boat known as a Collingwood skiff, ${ }^{18}$ and may be more closely related to this type than the Mackinaw boat. Collingwood skiffs were double-ended craft fitted with centreboards, and often ketch-rigged. Sails consisted of a jib attached to the bowsprit, a loose-footed gaff foresail, 


\section{THE MOWAT BOAT}
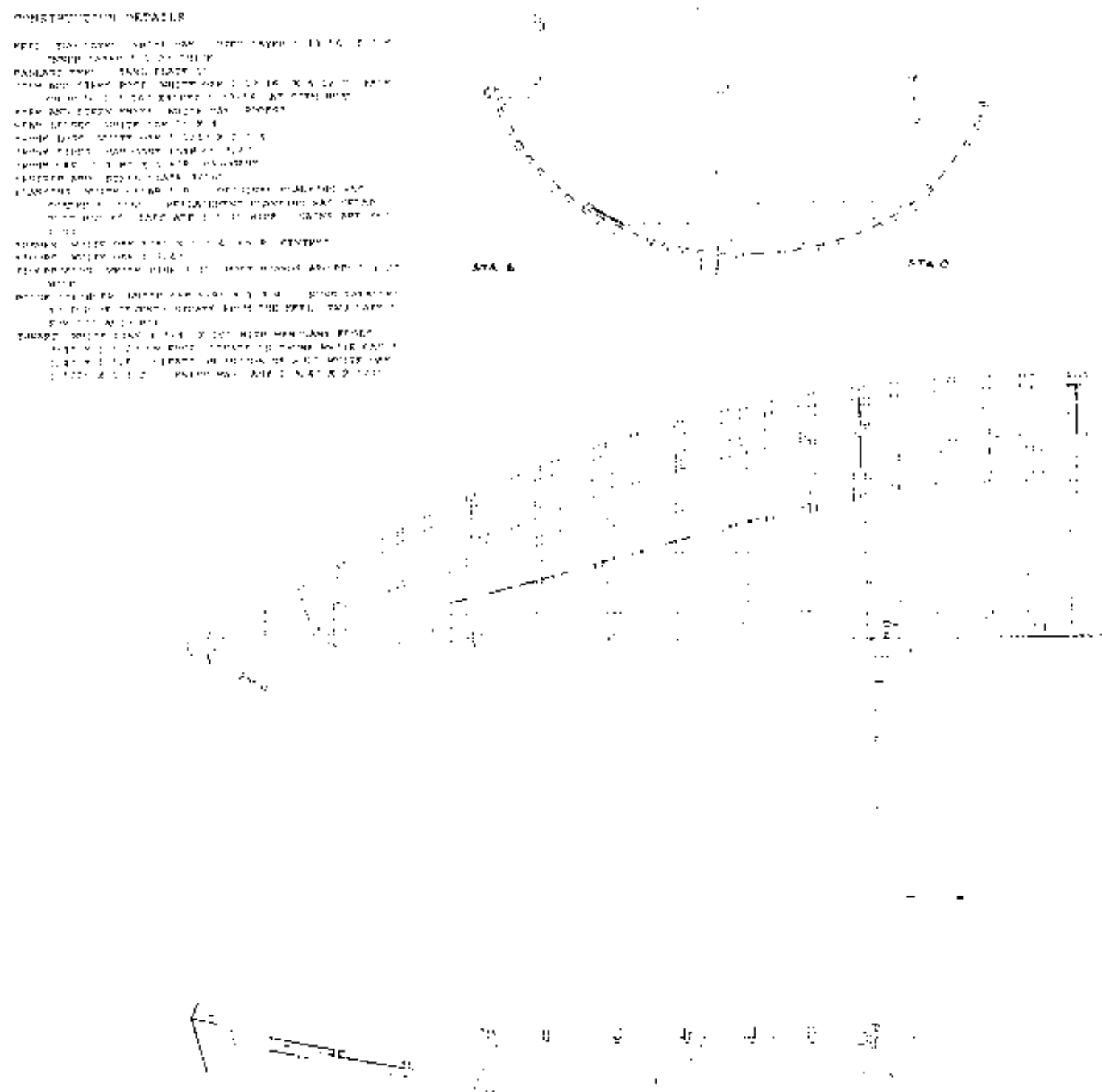

Figure 3. Lines of the Mowat Boat, showing its generally symmetrical shape fore and aft. Continued on opposite page. Source: Marine Museum of the Great Lakes, Kingston, Ontario (MMGLK), Archives 199. Note that there is a $12.7 \mathrm{~mm}$ (one half inch) overlap with figure $3 \mathrm{~b}$ opposite. 

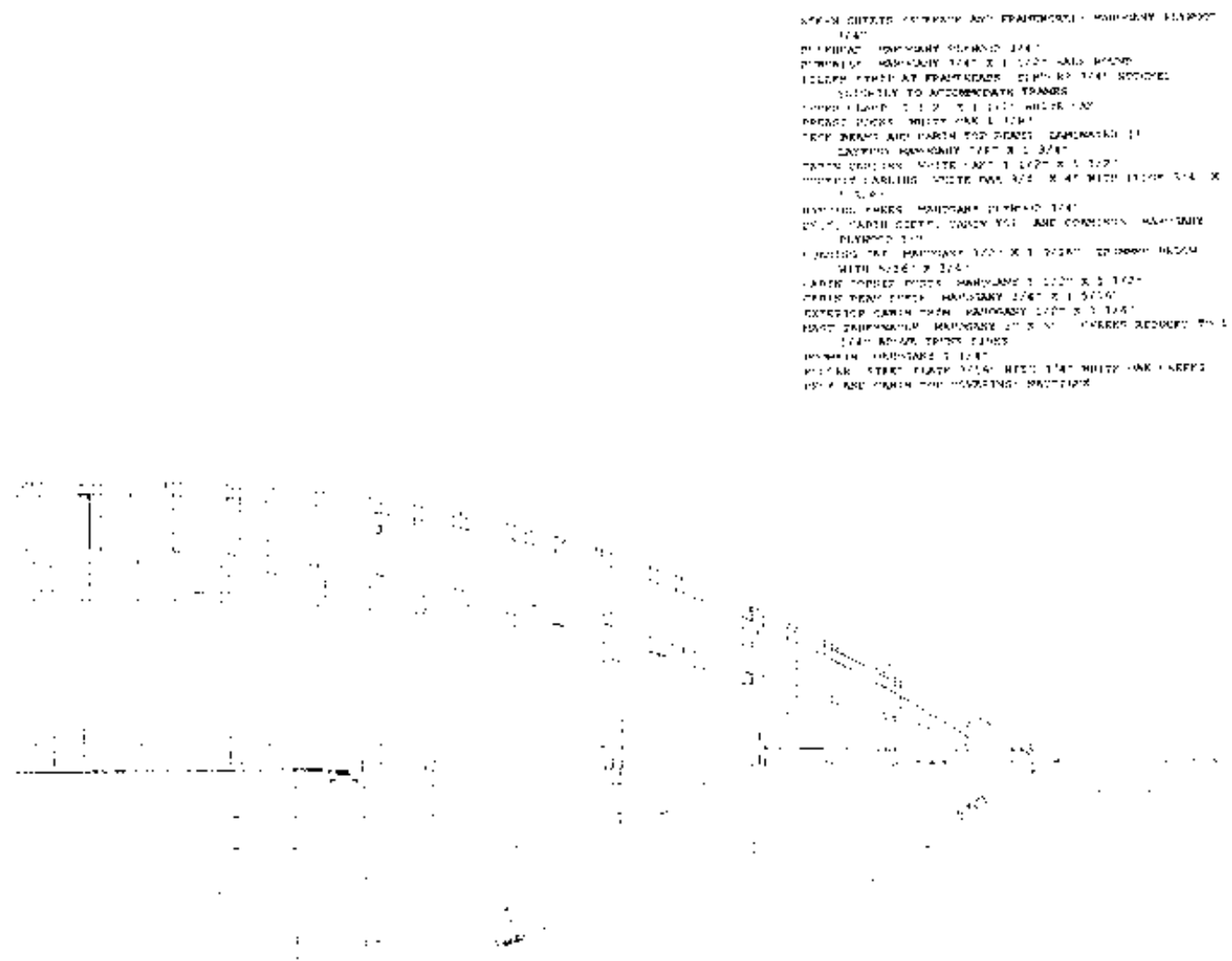

Figure 3b. Lines of the Mowat Boat, showing its generally symmetrical shape fore and aft. Continued from opposite page. Source: Marine Museum of the Great Lakes, Kingston, Ontario, Archives 199. 
and a mainsail that was either sprit or gaff-rigged. ${ }^{19}$ Collingwood boats were usually clinker-built, but examples with carvel planking were also constructed. ${ }^{20}$ They ranged in size from small rowboats of only a dozen feet or so in length to vessels over 40 feet long. ${ }^{21}$ Boats and the area of sail they carried increased in size over time as a response to depleted fish stocks, which required fishermen to travel greater distances. ${ }^{22}$ The characteristic features of a Collingwood skiff are apparent in figure 4.

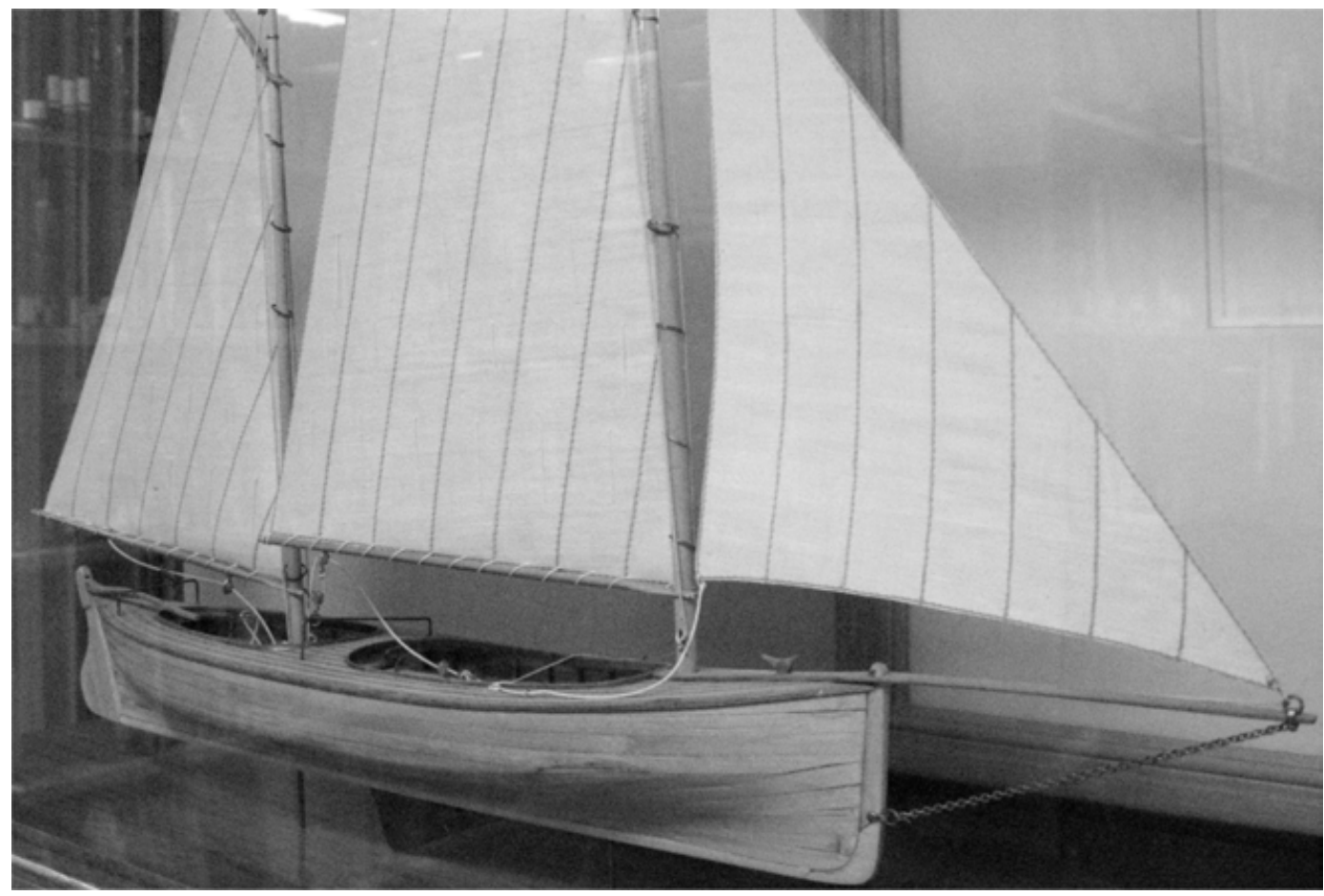

Figure 4. Characteristic features of Collingwood skiffs such as the double-ended symmetrical hull and the hogged down bowsprit are visible in this 1/24 scale model on display in the Audrey E. Rushbrook Library, at the Marine Museum of the Great Lakes. Source: author's collection.

Some sources claim that the Mackinaw boat developed from the Collingwood skiff, ${ }^{23}$ but this seems unlikely, as the Watts brothers who developed the latter type did

19 Philip Gillesse, Ten Historic Canadian Working Boats (Ottawa, ON: National Museum of Science and Technology, 1991), 94.

20 Maggie Leithead, Collingwood Skiffs and Side Launches (Collingwood, ON: The Collingwood Museum, 1994), 5.

21 Peter Watts and Tracy Marsh, W. Watts \& Sons Boat Builders: Canadian Designs for Work and Pleasure 1842-1946 (Oshawa, ON: Mackinaw Productions, 1997),32.

22 Gillesse 1991, 94.

23 James Barry, Georgian Bay: The Sixth Great Lake (Toronto: Clarke, Irwin and Company, 1971), 108. 
not arrive in Collingwood until $1850,{ }^{24}$ five years after Hyacinth Chenier had built the Mackinaw Wabesi. However, Philip Gillesse has pointed out that the construction date of 1845 for the Wabesi is based on oral history, which tends to exaggerate, and a working life of seventy years seems inordinately long for a wooden boat. ${ }^{25}$ Collingwood skiffs and Mackinaw boats were similar craft that were developed around the same time in reasonably close geographic proximity to each other, so it only natural that a confusing tangle of ideas has sprung up around their relation, if any, to each other. The matter is certainly not helped by the many authors who use the terms "Mackinaw" and "Collingwood" seemingly interchangeably. ${ }^{26}$ Collingwood skiffs can be distinguished from Mackinaws because they have generally finer lines and are symmetrical fore-andaft, and thus lack the distinctive bulging shape of Mackinaws. ${ }^{27}$ Again, the researcher in the area is likely to run up against the thorny issue of nomenclature. Just as with the Mackinaw, Collingwood skiffs were simply called "fish boats" by their users ${ }^{28}$ and the term "Collingwood skiff" wasn't used by the Watts until 1867 at the earliest, ${ }^{29}$ probably to add a distinctive cachet to their product and so firmly establish their brand.

The Watts brothers, Matthew and William, emigrated from Sligo, Ireland to Canada in 1843, when they were in their late teens or early twenties. ${ }^{30}$ They had apparently learned the craft of boatbuilding in their homeland, but it is difficult to discern the exact relationship between their Irish training and the boats they eventually produced in Canada. Watts and Marsh state that the brothers "incorporated many of their longstanding techniques of design and construction from native Ireland,"31 but do not go into specifics or provide any evidence to support this claim. However, the Watts were certainly of a sufficient age when they arrived in Canada to have imbibed a good deal of the boatbuilding craft, as it was as a tradition among boatbuilders to have a young boy or two on hand as an apprentice. ${ }^{32}$ A perfunctory examination of the boats used in County Donegal, just to the north of Sligo, reveals watercraft markedly similar to Collingwood skiffs. Boats known as Drontheims or skiffs are related to yawls, and may share a faint Scandinavian influence. ${ }^{33}$ They are clinker-built boats with a symmetrical shape fore and aft and fine lines. They carry sprit or gaff rigs on single masts set slightly forward of midships. If a bowsprit were added, these boats would not look too out of place sailing on Georgian Bay.

When the Watts brothers first came to Canada in 1843 they settled on Toronto

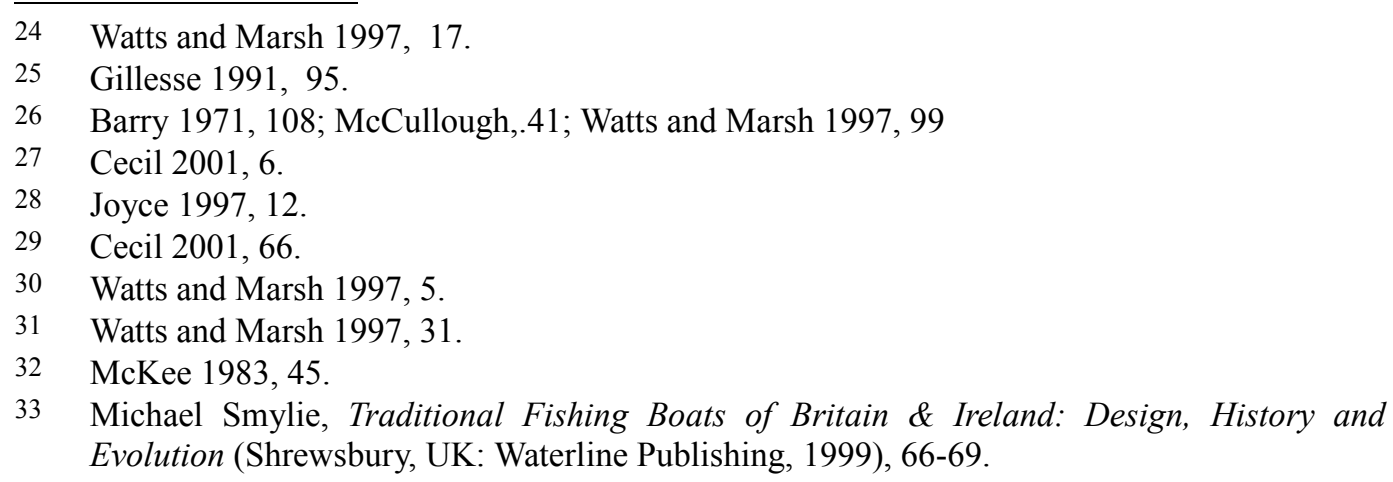


Island, and promptly began building double-ended lapstrake skiffs, ${ }^{34}$ perhaps similar to those they were familiar with in Ireland. It seems plausible that their boats were put to use for fishing, as a Mr. Geddes owned a commercial fishery on the island in 1846 that employed thirty to forty men. ${ }^{35}$ The ambitious brothers were not content to remain on the small island, and sensed new commercial opportunities to the west. They moved to the southern shores of Georgian Bay in 1850, and were churning out their double-ended skiffs a full two years before the railway arrived in 1855 to exploit the timber and other natural resources of the region. ${ }^{36}$ The 1870 s and early 1880s were the heyday of the Collingwood skiff, which began to decline in numbers after 1885 or 1886 due to the depletion of fish stocks and the introduction of more efficient steam-powered fish tugs. ${ }^{37}$ The Watts were savvy businessmen, however, and found diverse avenues to market their product. Watts boats were very popular as lifeboats on large iron or steel ships, and formed a vital lifeline for isolated lighthouse keepers. Collingwood skiffs were built to order and exported to waters as distant as James Bay and Lake Winnipeg. In 1870 Colonel Garnet Wolseley used nine Watts boats to help transport troops and supplies on his mission to suppress the Red River Rebellion. ${ }^{38}$ Wolseley thought so highly of the Collingwood boats that he used a fleet of 600 similar craft on his mission down the Nile to rescue General Gordon at Khartoum in $1884 .{ }^{39}$ Watts boats became very popular on the west cCoast as well. William Watts Jr. arrived in Vancouver in 1888 and found a large demand for fishing boats to supply the burgeoning salmon industry. Here the boats were christened 'Columbia River skiffs,' although they remained almost identical in form to the standard Collingwood skiff. This is yet another example of similar boats that received different names based on nothing more than the locality where they were employed. The west coast Watts boat yard was an extremely successful operation and remained in business until 1929. ${ }^{40}$ Based on this diaspora of Watts' design, it can be argued that Collingwood skiffs were the most successful type of Great Lakes small watercraft. From the design's early development at Toronto Island in the 1840s it was particularly prevalent on Lake Ontario, and it is entirely possible that the builder of Mowat boat, Scott Hutcheson, was influenced by the Collingwood skiffs.

\section{The Mowat Boat as a Sailing Fishing Boat, c.1910-1940}

In 1910 Hutcheson, a fisherman, decided to build himself a new boat near his home in the Barcovan Beach area of western Prince Edward County. A half-century later Angus Mowat described him in glowing, almost rapturous, terms as a "man of character"

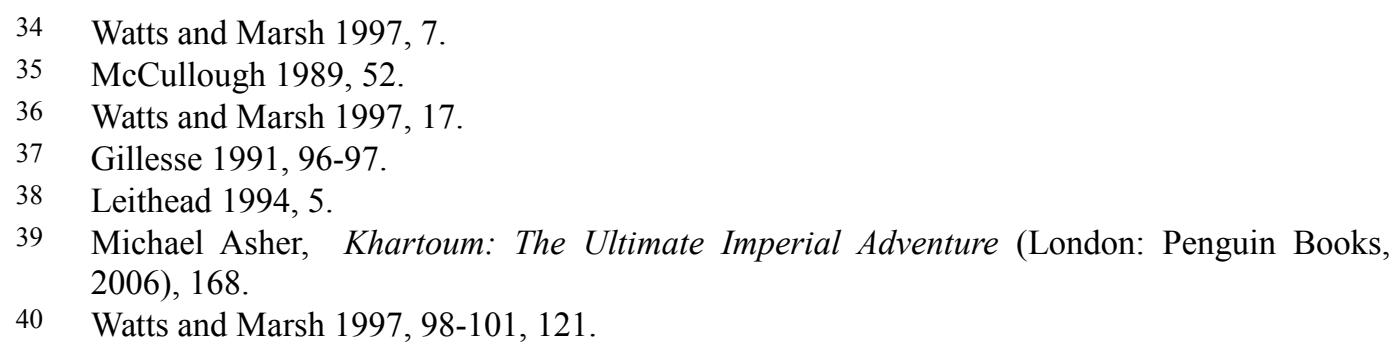


who was also a "poet and an artist." ${ }^{41}$ Most information about Hutcheson comes from oral sources recounted many years after his death, and as already noted in the case of the Wabesi, memories become gilded with the passage of time. One source says Hutcheson was already in his sixties ${ }^{42}$ when he began building what would eventually become the Mowat Boat, although this would make him exceptionally long-lived if he continued to operate the boat until 1940, as a later newspaper article claims. ${ }^{43}$ Hutcheson, as a fisherman, had previously built and owned other boats. His granddaughter, Elizabeth Hutcheson Keller, remembers one called the Donna, before Scott Hutcheson and his son (her father) built what they called the "Big Boat." ${ }^{, 4}$ Like many working boats before and after her, there is a good chance that the vessel that later became known as the Mowat boat was originally anonymous, and referred to by her users according to such characteristics as her size and colour.

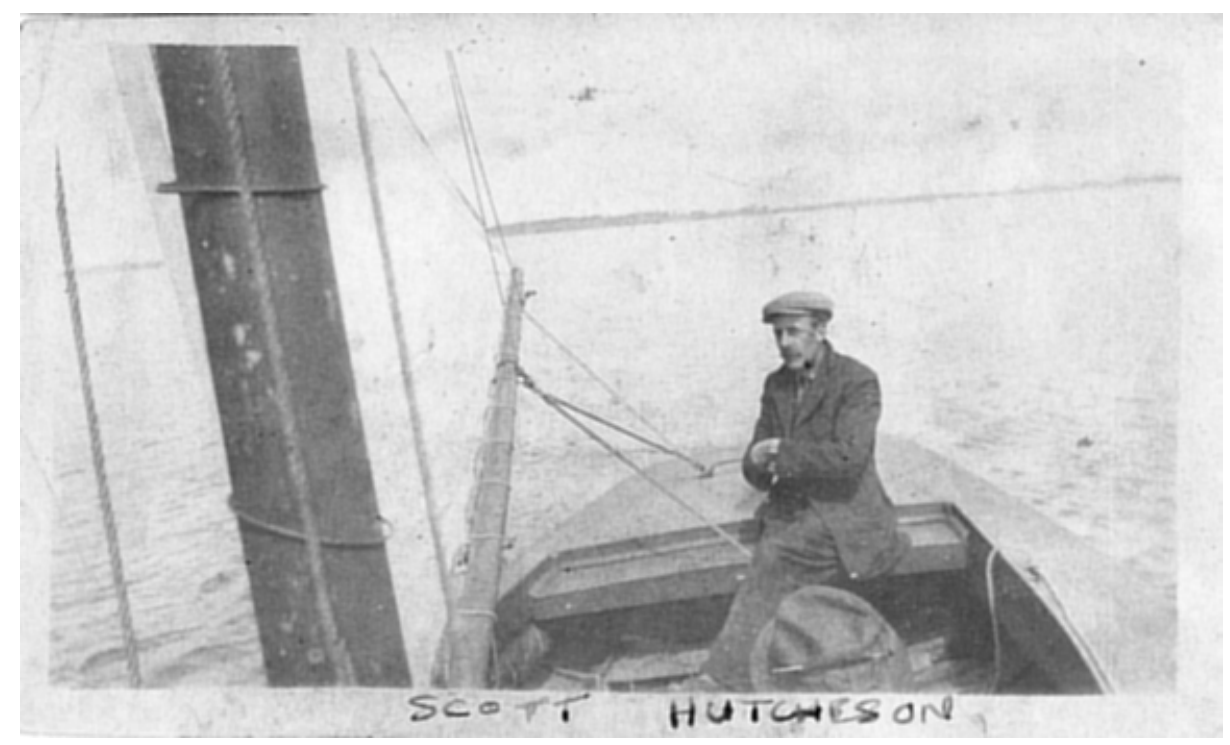

Figure 5. Scott Hutcheson at the helm of the boat he built in 1910. Source: MMGLK Coll. Doc. Files 1998.0030.0001-0002.

Scott Hutcheson can be considered an amateur boat builder, in the sense that he did not work full-time in a boat yard. Fisherman built the boats they needed, as a way to save money and to incorporate desired features, using local techniques. This "do-ityourself" trend was noted in 1884 by Henry Hall during his survey of the American shipbuilding industry for the U.S. government. "A great many boats are the work of men

41 Angus Mowat to Kingarvie, 13 July 1969, Marine Museum of the Great Lakes Kingston, Collection Documentation Files [MMGLK] 1998.0030.0001-0002.

42 Al Purdy, "The Old Man and the Boat," Weekend Magazine (27 April 1974), 8.

43 Ronalde Gibson, "A Unique Boat and a Unique Man: Angus Mowatt [sic] Visits Home Town," The Trentonian, 9 September 1974.

44 Email from Elizabeth Hutcheson Keller to Peter Cobbett, 6 February 2007, MMGLK 1998.0030.0001-0002. 
half fishermen, half carpenter, who make only one boat, or at most two or three boats in a year. It is a modest industry, and is the means of utilizing the spare time of a great many men whose labor [sic] would otherwise find only partial employment." ${ }^{.45}$ Fishing was a seasonal occupation, so Hutcheson would have been able to build the boat in the off season, the winter and early spring, with help from his son, as his granddaughter remembers. Angus Mowat was seventeen in 1910 and apparently would ride his bicycle from nearby Trenton to watch the boat taking shape ${ }^{46}$ perhaps sparking his lifelong love of this craft.

\section{Construction Characteristics}

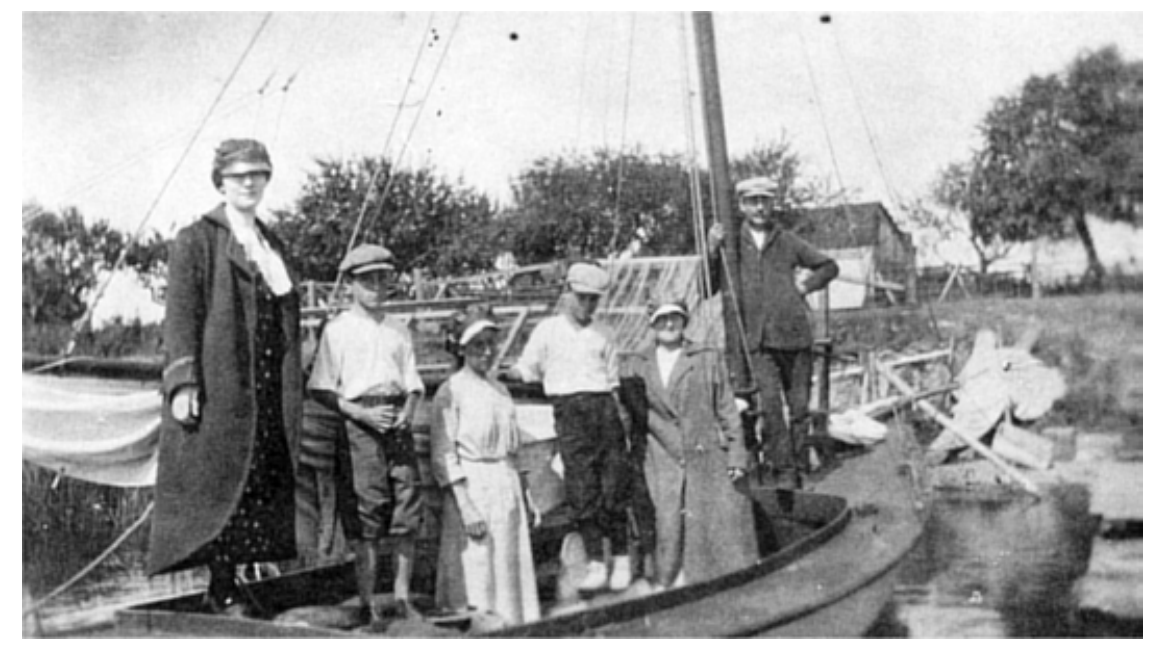

Figure 6. The Mowat Boat as originally built by Scott Hutcheson. She is sparred as a sloop, with a gaff rig and is partially decked, with a rectangular cockpit. Source: MMGLK Coll. Doc. Files 1998.0030.0001-0002.

Since the boat underwent at least two substantial remodellings, it is difficult to know all the specifics of her original construction. Evidence can be gleaned through the careful study of three contemporary photographs of her (figures 5, 6, and 7), and from records kept during the remodelling done by Mowat and the restoration done by the volunteers at the Marine Museum. This process of working backwards from a known point in time can be called "the direct historical method," and is a technique often employed by archaeologists. As built in 1910, the boat was a double-ended craft with lapstrake planking, a moderate sheer, and nearly plumb stem and stern posts. It is likely that pine or cedar was used for her outer shell of planks, while oak formed her keel, keelson, stem and stern posts, and frames. The wood was probably obtained locally, much as Mowat did nearly sixty years later. Hutcheson would have built the boat using simple hand tools, and her eventual shape was the outcome of his practiced eye alone.

45 Henry Hall, Ship-Building Industry in the United States (Washington, DC: Government Printing Office, 1884), 43. 
Commercial boat building operations like the Watts' used moulds and drawings to give their products a consistent shape, ${ }^{47}$ but a fisherman like Hutcheson who built only a few boats at most would have relied on experience, traditions, and "rules-of-thumb." Hutcheson economized where he could, by using locally available timber and the free labour of himself and his family, but also used more expensive materials where they were warranted. It is likely he used copper nails to fasten the edges of the strakes together, as copper is more resistant to corrosion than ferrous metals and thus would result in a boat that held together longer. When Mowat replaced the garboard strake (the lowermost hull plank, parallel to the keel) in 1968 he cut through about 300 copper nails with a hacksaw. ${ }^{48}$ It is possible that Hutcheson did not buy the building materials he needed with cash, but instead paid his suppliers in kind, with promises of the future fish he would catch in the boat. A blacksmith in Bronte, Ontario, for example, charged the local fishermen twenty-five cents per pair of oarlocks, but always to be paid in fish. ${ }^{49}$

Figures 5, 6, and 7 show a partially decked boat with a rectangular cockpit, a practical design to help keep waves out. The boat is sparred as a sloop, with a single mast

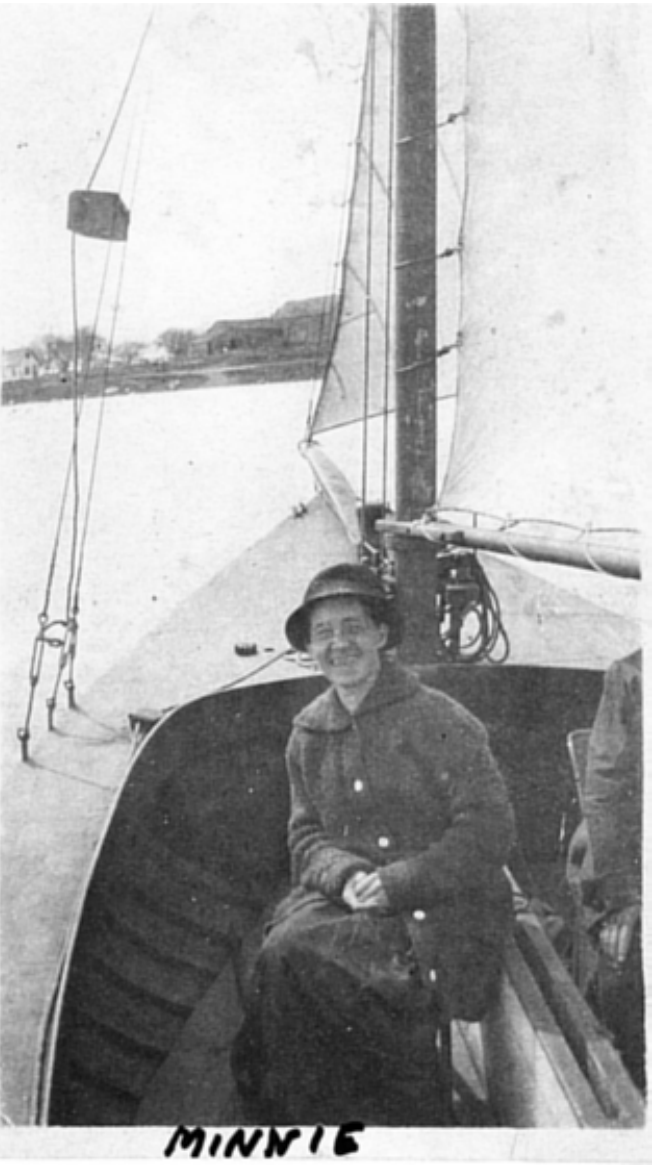

Figure 7. In this other contemporary view of the Mowat Boat the centreboard trunk is visible in the right foreground. Source: MMGLK Coll. Doc. Files 1998.0030.00010002 . well forward of amidships, but not so far forward as to be "in the eyes," and there is also a bowsprit. The mast is supported by forestays and shrouds, and carries a gaff rig with a boom as well as a jib. As already noted, this fore-and-aft rig was the preferred one on the Lakes, as it could be handled by only one or two men, while providing sufficient speed to outrun foul weather or rush fish to market. No ballast is visible in the photos, but fish boats of this type usually carried about a ton of ballast in the form of loose stone or bagged sand or gravel. This ballast could be shifted as dictated by conditions, or dumped to make way for a haul of fish. ${ }^{50}$ In figure 7 a centerboard box can be seen in the

47 Watts and Marsh 1997, 159.

48 Angus Mowat to Perry, 15 May 1968, MMGLK 1998.0030.0001-0002.

49 Joyce 1997, 8.

50 Joyce 1997, 8. 
foreground. Neither oars nor oarlocks are visible in the photos, but it is likely oars or paddles were stowed on board for assistance in calms or when docking.

One of the most pressing questions about the Mowat Boat in its original incarnation concerns the matter of motorization. The photos give no indication of an engine on board, and show a boat fully rigged with sails as its primary motive force. Mowat was vehement in his insistence that Hutcheson had never used an engine, variously declaring "I'll put her back in sail just as Scott built her,"51 "he [Hutcheson] never used an engine either, not to his dying day," 52 and most colourfully "[Hutcheson] swore he'd be the last man on Lake Ontario to defile God's winds with the smell of a stinking engine. ${ }^{\prime 53}$ The photos seem to confirm Mowat's vitriol, and there the matter would rest, were it not for a newspaper report that "the boat was renowned locally as the boat with two motors," which were apparently Star 4-cylinder engines. ${ }^{54}$ Hutcheson's boat certainly looks like it was originally built as a sailboat, but it is possible it was converted to motor power sometime during the thirty or so years that he operated her.

\section{Commercial Fishing on the Great Lakes}

Hutcheson's granddaughter recalls "getting up early and going out on Lake Ontario to pull the nets, take the yellow perch to shore, [and] get shaved ice from the ice house to chill the fish until we took them to the fish house to sell them." ${ }^{55}$ This important recollection shows he was using gill nets, a type that was long and rectangular, and made of fine thread. The nets were set in open water, and were kept upright by floats along the top edge and weights along the bottom edge. Early floats were of cedar, which were later replaced by cork, while stone weights were superseded by lead weights in the mid nineteenth century. Nets were made of linen, but later of cotton and eventually nylon. It is possible that Hutcheson continued to use linen nets long after they had been abandoned elsewhere, for linen nets were used on Lake Ontario as late as 1950. The nets were handmade, and their production and maintenance was one of the significant roles women played in the Great Lakes fishing industry. After 1840 machine made nets began to be imported from Scotland. Gill nets were treated with kerosene or slaked lime as a preservative, and were dried daily if the weather permitted. ${ }^{56}$

As their name suggests, gill nets functioned by snaring fish by the gills, and the size of a net's mesh would be based on the type of fish desired. Several nets could be joined together to form a "box," and multiple boxes would form a "gang." The trend was for nets to become longer over time, as fisherman increased the intensity of their operations in an attempt to combat diminishing returns brought about by over-fishing, in a vicious cycle of over-exploitation. In Georgian Bay in the 1890s a common setup of six

51 Angus Mowat to Marion Mills, 11 December 1967, MMGLK 1998.0030.0001-0002.

52 Angus Mowat to John Gardner, undated [ c.1967-1968], MMGLK 1998.0030.0001-0002.

53 Mowat to Kingarvie, 13 July 1969, MMGLK 1998.0030.0001-0002.

54 Gibson 1974.

55 Keller to Cobbett, 6 February 2007, MMGLK 1998.0030.0001-0002.

56 McCullough 1989, 32. 
boxes would form a gang about 3,000 metres in length, but by 1905 gangs were formed of eighteen to twenty boxes with a combined length of over 14,000 metres. While the length of nets increased over time, their width remained relatively constant at around two metres. ${ }^{57}$

The two other types of nets used on the lakes were seine nets and pound or trap nets. Seine nets were long nets that were stretched out into the water in an arc from two points on shore. Seine nets could occasionally make enormous catches, such as when they were set up along a spawning route, and could be operated by unskilled labourers. However, seine nets by their nature could not easily be relocated, and beginning in the 1890 s they began to be banned, as it was believed their dragging along the bottom killed fish spawn. ${ }^{58}$ On Lake Erie the preferred type was pound or trap nets. These nets were hung from wooden posts driven into the lake bottom, and had long "leads" of heavy tarred netting that funneled the fish into a net box, or "crib," where they were trapped. The tarred netting ensured that it could be left underwater for long periods of time, and was also visible to the fish. Pound and trap nets were highly effective, and kept the fish alive in the crib. ${ }^{59}$

Fish caught by the gills in gill nets would die if not removed promptly, and consequently fetch a lower price. This would necessitate Hutcheson's early morning trips to "pull the nets." The shape of Hutcheson's boat was well designed for the work he had to do. Nets were hauled in over the stern of the vessel. The boat would first move to the downwind buoy, and raise the centerboard, ship the rudder, and swing the main boom forward in preparation for retrieving the nets. The nets were hauled in hand over hand when the boat dropped into a trough, and braced under the coaming when the boat was rising on a swell. The shoal draft and sharp stern reduced resistance against the water as the boat moved backward while the nets came aboard. The size of the boat was ideal, at slightly less than twenty-eight feet in length. This was about the maximum size that two men could manage to handle and haul in the gill nets. A boat larger than thirty feet in length would have required a third man, and so reduced the profits. ${ }^{60}$ Gill nets were the most practical for a small business, as they were cheap in comparison to other types of equipment. In 1890 a boat with a gang of gill nets could be had for about $\$ 500$, while the equivalent boat with a pound net setup would cost about $\$ 1000 .{ }^{61}$ Gill nets required fewer men to handle and maintain than the elaborate pound nets, which required work crews to drive piles into the lakebed. Gill nets were also more flexible than seine or pound nets, since they could more easily be retrieved and set in a new location.

Hutcheson would likely have fished in waters close to home, such as Presque'Ile Bay. Fishermen on the Great Lakes would work long hours during the peak times of year,

57 McCullough 1989, 28-29.

58 McCullough 1989, 23, 26.

59 Timothy C. Lloyd and Patrick B. Mullen, Lake Erie Fishermen: Work, Tradition, and Identity (Urbana, IL: University of Chicago Press, 1990), 12.

60 Joyce 1997, 2, 4.

61 McCullough 1989, 29. 
but almost always returned home by nightfall. ${ }^{62}$

It seems likely that he sold his catch to a local middleman. From his granddaughter's recollection quoted above, it is evident he The "fish house" that Elizabeth Hutcheson Keller mentions was the place where the fish were processed and prepared for shipment. Depending on the market and time period, fish could be shipped whole or partially gutted, while fillets became popular in the $1920 \mathrm{~s} .{ }^{63}$ The fish would be preserved either by chilling it using natural blocks of ice, or freezing using the ammonia or chilled brine processes. The fish would be bought by American middlemen for shipment to the United States, or alternatively sold locally within Ontario.

Elizabeth Hutcheson Keller remembers that her grandfather used to catch yellow perch. The preferred catch of early fishermen on Lake Ontario had been lake salmon, but over-fishing combined with the destruction of spawning streams meant that they had become extinct by about 1860 . Fishermen moved on to harvesting whitefish and lake trout ${ }^{64}$ and by the early twentieth century fishermen like Hutcheson were making do with less desirable species like yellow perch. Local and federal authorities had been concerned over declining fish stocks since the mid-nineteenth century, but conservation legislation did little to avert the drastic decline of most fish species. Fishermen like Hutcheson were undoubtedly acutely aware of dwindling fish stocks, but often blamed the middlemen and fish agents for driving down prices. Low prices further aggravated the situation as fishermen sought to catch ever more fish to provide for themselves and their families. ${ }^{65}$ Being a fisherman on the Lakes was certainly not an easy life, but it had its own rewards and it was a lifestyle that continued to be practiced by independently minded individuals, such as the next owner of Hutcheson's boat.

\section{The Mowat Boat as a Motorized Fishing Boat, c. 1958-1968}

Much of the history of the Mowat Boat between the time of its construction by Scott Hutcheson and its rebuilding by Angus Mowat nearly sixty years later is dogged by uncertainty and contradiction. This situation is is common for working boats, as they were so often taken for granted except by their immediate users, chronically underrepresented in the written record. ${ }^{66}$

A newspaper article in The Trentonian, of Trenton, Ontario, records that Hutcheson used the boat up until $1940 .{ }^{67}$ It is possible that the boat was then abandoned and lay derelict. Mowat recalled that he found the boat "in 1954...lying alone on the beach, dying, lying over with her starboard bilge half full of sand and shingle...But it wasn't her end. George Offen took her."68 The newspaper article also mentions George

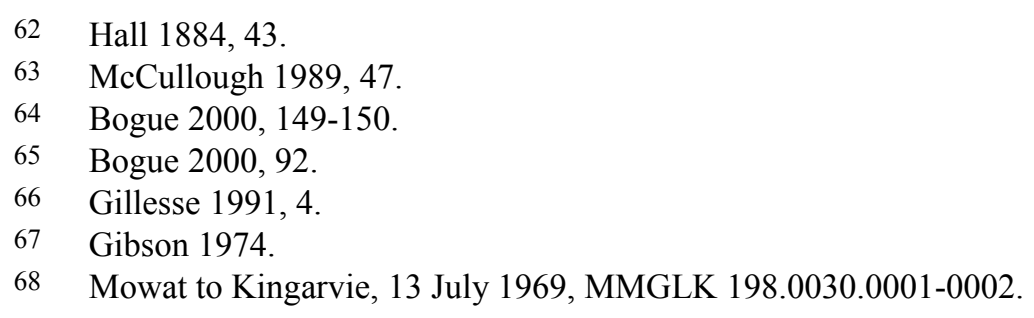


Offen, but states that he bought the boat from Hutcheson in $1940 .{ }^{69}$ Here are two contradictory versions of events. If Offen had owned the boat since 1940 and had abandoned her by 1954, when seen by Mowat, it seems unlikely that he would take the boat back again, as stated by Mowat. If Mowat's recollections are correct, then perhaps the boat was abandoned from about 1940 to 1954, at which point she was repaired by George Offen. The story becomes much better documented after 1958, when the boat was owned by a fisherwomen named Marion Mills.

\begin{tabular}{|c|c|c|c|c|c|c|c|}
\hline & $1910-1940$ & 1940-1954 & 1954-1958 & $1958-1968$ & $1968-1977$ & 1977-1989 & $\begin{array}{l}1989- \\
\text { Present }\end{array}$ \\
\hline Owner & $\begin{array}{l}\text { Scott } \\
\text { Hutcheson }\end{array}$ & Unknown & $\begin{array}{l}\text { George } \\
\text { Offen }\end{array}$ & Marion Mills & Angus Mowat & $\begin{array}{l}\text { Andy } \\
\text { Thomson }\end{array}$ & MMGLK \\
\hline Name & Unknown & Unknown & Unknown & Lake-ly & $\begin{array}{l}\text { Aongeos } \\
\text { Dubh, later } \\
\text { Scott } \\
\text { Hutcheson }\end{array}$ & $\begin{array}{l}\text { Scott } \\
\text { Hutcheson }\end{array}$ & $\begin{array}{l}\text { The } \\
\text { Mowat } \\
\text { Boat }\end{array}$ \\
\hline Event & $\begin{array}{l}\text { Built by } \\
\text { owner }\end{array}$ & $\begin{array}{l}\text { Abandone } \\
\mathrm{d} \text { derelict }\end{array}$ & $\begin{array}{l}\text { Possible } \\
\text { reconstruct } \\
\text { ion }\end{array}$ & Rebuilt & $\begin{array}{l}\text { Rebuilt as } \\
\text { yacht }\end{array}$ & In storage & $\begin{array}{l}\text { Museum } \\
\text { restoration }\end{array}$ \\
\hline Propulsion & $\begin{array}{l}\text { Sail, sloop } \\
\text { rig, } \\
\text { possibly } \\
\text { motor }\end{array}$ & N/A & Motor? & $\begin{array}{l}\text { Motor - } \\
4 \text { cyl. gas } \\
\text { inboard }\end{array}$ & $\begin{array}{l}\text { Sail, Marconi } \\
\text { sloop rig, } \\
\text { Outboard } \\
\text { motor }\end{array}$ & $\begin{array}{l}\text { Sail, } \\
\text { Marconi } \\
\text { sloop rig, } \\
\text { Outboard } \\
\text { motor }\end{array}$ & $\begin{array}{l}\text { Sail, } \\
\text { Marconi } \\
\text { sloop rig }\end{array}$ \\
\hline Use & $\begin{array}{l}\text { Fishing } \\
\text { boat }\end{array}$ & N/A & $\begin{array}{l}\text { Fishing } \\
\text { boat? }\end{array}$ & Fishing boat & Yacht & None & $\begin{array}{l}\text { Museum } \\
\text { piece }\end{array}$ \\
\hline
\end{tabular}

Table 2. The postulated ownership history of the Mowat Boat.

According to Angus Mowat, after the boat was owned for a time by George Offen, she was sold to a local woman, Marion Mills, figure 8. It is likely that this occurred in 1958, as in a series of photographs dated that year, a boat that looks very much like the Mowat Boat is being moved off a beach. Marion Mills was born in Brighton, Ontario and as the eldest of fourteen children, learned the art and skills of commercial fishing from her father. Most of the information about Mills comes from a newspaper article written in 1961, according to which she "has been doing this job for twenty years and is believed to be the only woman who fishes alone and on such a large scale." ${ }^{, 70}$ As with most fisher folk on the Lakes, fishing was not the only source of income for Mills, and she also ran a small holiday camp at Barcovan Beach. ${ }^{71}$

\section{Construction Characteristics and Modifications}

Marion Mills called her boat Lake-ly, and she, or the owner after Scott Hutcheson, had converted it to motor power - gone were the mast and bowsprit. The partial decking remained, and the cockpit was ovoid in shape. The biggest change was the installation of a large, square deckhouse in the centre of the boat, visible in figure 9 . The

69 Gibson 1974.

70 Lloyd Thompson, "Lake Holds No Terror for Woman,” The Globe and Mail, 15 June 1961.

71 Lloyd Thompson, Marion Mills Story - Draft of "Lake Holds No Terror for Woman," 1961, MMGLK 1998.0030.0001-0002. 


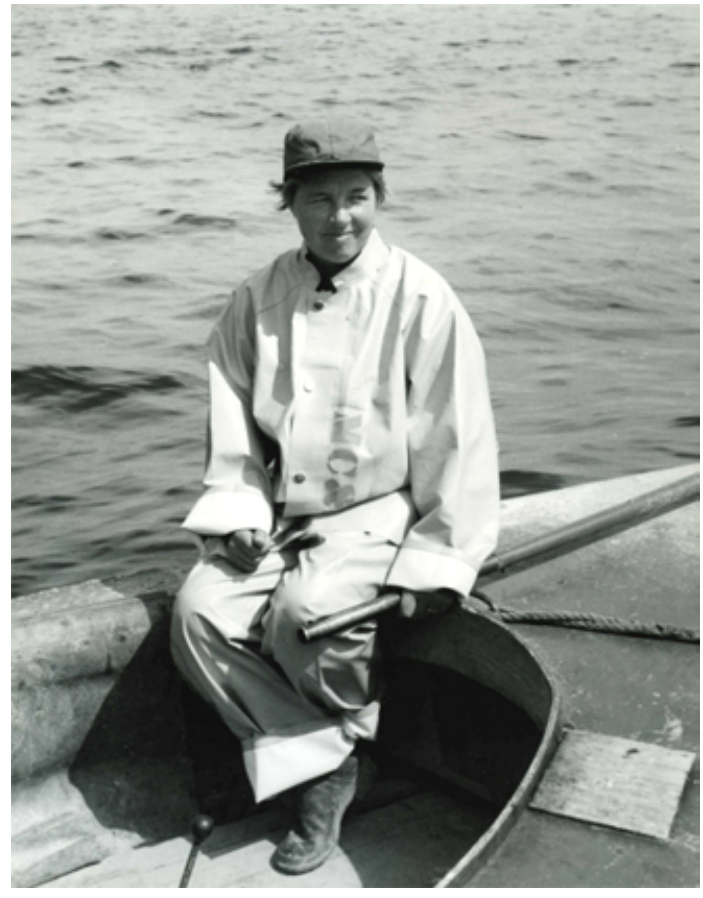

Figure 8. Marion Mills, the fisherwoman who owned the Mowat Boat from 1958-1968 and operated it as a motor-driven commercial gill net boat. Source: MMGLK Coll. Doc. Files 1998.0030.0001-0002. deckhouse looks to be about four feet high, and has windows on all sides, with doors to access the forward and aft portions of the boat. The construction of the deckhouse may have been a result of the change to motor power. Motor boats are wetter and colder than sail boats, as they have the ability to go directly into the wind and waves, and there are fewer tasks to keep the crew warm. ${ }^{72}$

The Lake-ly was powered by a four-cylinder, presumably gasoline, engine, which sometimes broke down far from shore. In figure 8 what looks like a gear shift lever is visible in the lower foreground, and in figure 9 Mills is standing on a box located amidships, of just the right size and shape to contain an inboard engine. The presence of the engine is also indicated by black staining on the hull from the exhaust. The boat could also be propelled using oars, visible on top of the deckhouse in figure 9, and in another photograph it appears Mills is using an oar to scull the boat.

Scott Hutcheson's sailing fishing boat was already something of an anachronism when he built it in 1910, as steampowered fishing tugs began to be introduced in the 1870s. Fish tugs required considerable capital investment, but they were more efficient than small sailing fishing boats because they could stay out longer, and in rougher weather. They were also faster than sail boats, and so spent less time travelling, and could apply steam power to labour-saving devices such as powered net-lifters. ${ }^{73}$ Steam plants were obviously impractical for small boats, but gasoline engines provided a relatively compact and affordable power plant. The Reid Gasoline Engine Company had been established in Hamilton, Ontario in 1895, and in 1910, while Hutcheson was sparring his sleek sailing craft, many other fishermen were taking masts and spars down and installing engines instead. At first engines were only used in calms or to assist getting around in harbour, and vestigial sailing rigs remained. However, by the end of the First World War most sails had disappeared, and the last trip of the Bronte, Ontario fleet of sailing fishing boats to Main Duck Island was in $1923 .^{74}$

\footnotetext{
$72 \quad$ McKee 1983, 156.

73 McCullough 1989, 42.

74 Joyce 1997, 11.
} 


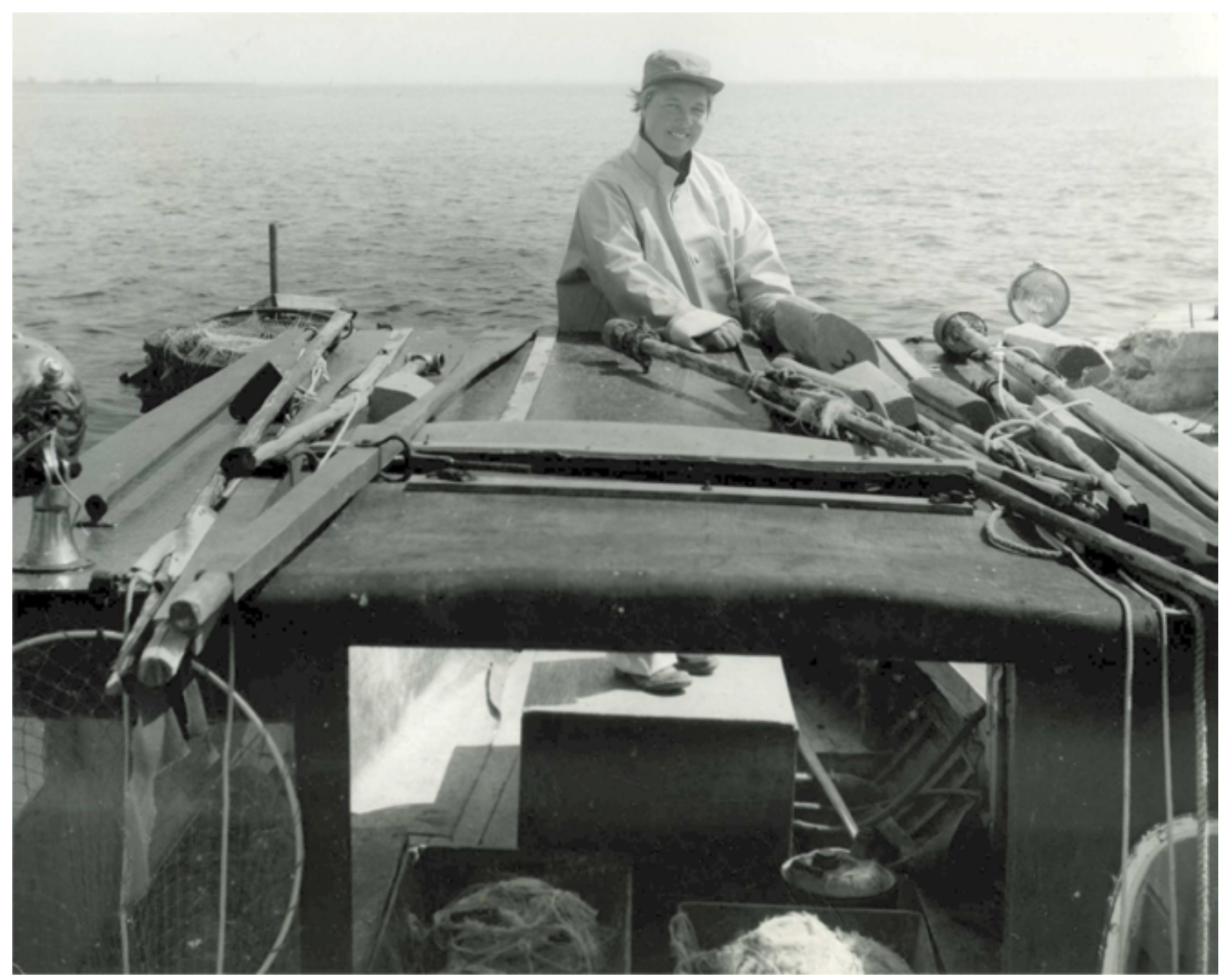

Figure 9. Mills is standing on what looks like the cover of an inboard engine, and nylon nets and and oars are visible on top of the deckhouse. Source: MMGLK Coll. Doc. Files 1998.0030.00010002.

The adoption of motor power necessitated a number of changes in the design of wooden boats. Carvel construction tended to replace lapstrake, as the former was more resistant to vibration caused by an engine. The area of the hull where the engine was mounted usually needed to be strengthened with additional framing and an engine bed to handle the added weight and vibration. Certain shapes of boat also lent themselves more easily to conversion to motor power than others. A boat with a relatively fine and narrow stern like the Lake-ly was poorly suited for engine installation, as a hole would have to be bored through the stern post to accommodate the propeller shaft. Rudder assemblies often had to be modified as well to allow sufficient space for the propeller. ${ }^{75}$ Boats with square or transom sterns were much better suited for motorization, and as a result they became the preferred form as gasoline and diesel-powered boats became the dominant type on the lakes in the 1920s. One of the more interesting aspects of the switch from sailing to motor boats is the speed with which the new technology was adopted, within the span of a single generation. Many observers have commented on the intense conservatism of 
traditional boatbuilders, where certain shapes are passed down for generations, and considered this conservatism to be innate. ${ }^{76}$ The swift adoption of a somewhat novel and untested new technology shows that fishermen and other professional boat people were not necessarily adverse to new technologies, and could even adopt them wholesale when the benefits were tangible, a point admirably made by Philp Gillesse. "Considering how hard their lives were, the alacrity with which fishermen and other boatmen accepted power is not surprising. What a pleasure it must have been for men used to rowing heavily burdened boats against winds and currents to stand up in a breeze with only a tiller in their hands." ${ }^{77}$ While romantics such as Angus Mowat may have bemoaned the passing of sailing boats, perhaps the people who earned their livelihoods aboard them in all weathers were not quite so nostalgic.

\section{Developments in Commercial Fishing on the Great Lakes}

Marion Mills probably used gill nets similar in size and shape to those used by Scott Hutcheson, but now the material was greatly improved. Nylon gill nets began to be introduced around 1950, and were both lighter and stronger than traditional cotton or linen nets. They required less maintenance, since they dried quickly and never needed tarring. Nylon nets were up to three times more efficient than earlier nets, since the fish could not see them. ${ }^{78}$ The work of setting and retrieving the nets remained much the same. They still had to be removed before storms and had to be checked regularly, lest the fish die and reduce their value. Marion Mills often fished as far as 20 kilometres from shore, in waters up to 40 metres deep. ${ }^{79}$

Another notable change from the days of Scott Hutcheson was in the fish stocks. Over-fishing and pollution had increased in the half-century since the boat had first touched the waters, despite government studies and efforts at conservation. Lake Ontario was not as severely affected by industrial pollutants as was Lake Erie, but the fish were still seriously depleted. Parasitic species such as the sea lamprey also harmed the Lakes fisheries. Lampreys had passed from Lake Ontario to Erie by 1921, where they did not do too much damage, but lampreys nearly destroyed the whitefish and trout fisheries of Lake Huron when they arrived in $1932 .{ }^{80}$ The fishing industry responded to depleted fish stocks in the only way it knew how, by increasing the intensity of fishing and perpetuating the cycle of over-exploitation. In the early 1950s trawlers were introduced to Lake Erie, where they could haul in enormous numbers of smelt, a species which before had always been considered too small to be economically viable.

76 Colin Palmer, “The Evolution of Traditional Boat Design: A Different View," Maritime Life and Traditions 8 (2000), 84.

77 Gillesse 1991, 10.

78 McCullough 1989, 32.

79 Thompson 1961, 2.

80 Bogue 2000, 330. 


\section{The Mowat Boat as a Yacht, 1968-1989}

Marion Mills decided to retire from fishing in 1967 and was going to sell her boat to local divers for $\$ 125$, until Angus Mowat came along. Mills was leery of selling to the divers, worrying that "they'd abuse the hell out of her," ${ }^{81}$ and instead sold the boat to Mowat, who had fallen in love with the craft he had watched take shape long ago. Mowat insisted on paying Mills $\$ 175$ for the boat,$^{82}$ which he then had moved to his rustic cabin near Harrowsmith, Ontario, in December $1967 . .^{83}$

Although the memory and achievements of Angus Mowat have been considerably eclipsed by those of his famous son, he was no less a romantic and adventurer. Angus McGill Mowat was born in Trenton, Ontario, in Prince Edward County in 1893 . He served with the $4^{\text {th }}$ Battalion of the Canadian Expeditionary Force in the First World War and saw action at the Somme and Vimy Ridge, where he lost his left arm. After the war he married his first wife, Helen, and worked at such diverse jobs as beekeeper and fire ranger. Mowat became the librarian at Trenton in 1924 and continued his literary interests by later publishing two novels. ${ }^{84}$ Mowat had always been something of a

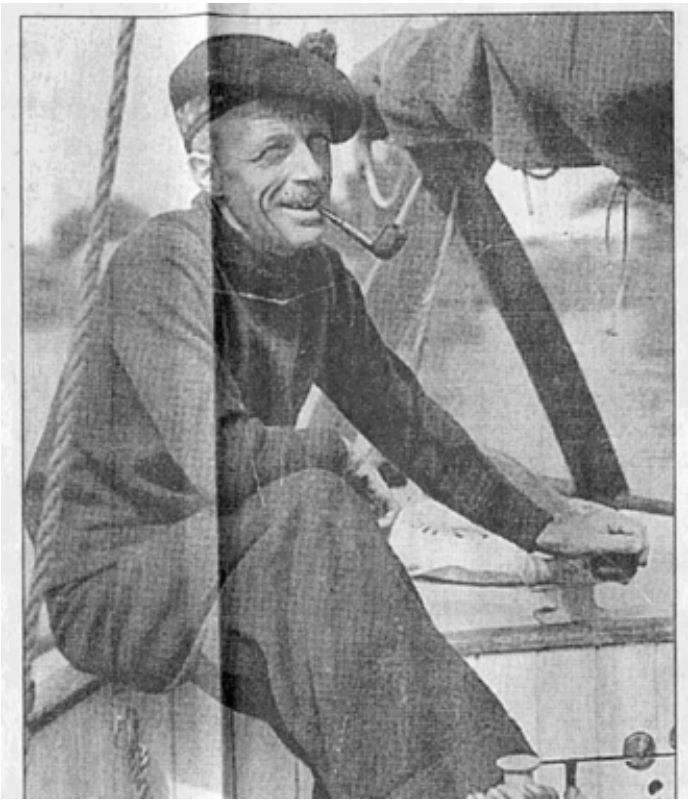

Figure 10. Angus McGill Mowat, 1893-1977, father of the famous author and avid lifelong sailor. Source: unknown, adapted from Corbett 1999. sailor and small craft enthusiast, owning a yacht called the Scotch Bonnet for over twenty years. In 1967 Mowat was 75 years old and had settled down in Pinchpenny, near Harrowsmith, Ontario, with his second wife, Barbara, "in a one-room cabin with a well, a woodpile, a backhouse, no electricity...a dog, my tools, books, and greater contentment, I believe, than any man has a right to." 85

Despite his professed contentment with the simple country life, it seems the siren song of the lakes was luring Mowat back to the waves, and he was contemplating building a boat. He wasn't quite sure what type of boat he would build, but he was sure of one thing - it would not be fiberglass! "Glass may be efficient but I'll never like it. It doesn't smell like a boat, and when you sit on a glass seat in a glass cockpit it is just like

81 Mowat to Gardner, undated, MMGLK 1998.0030.0001-0002.

82 Mowat to Mills, 11 December 1967, MMGLK 1998.0030.0001-0002.

83 Mowat to Kingarvie, 13 July 1969, MMGLK 1998.0030.0001-0002.

84 Purdy 1974, 10.

85 Mowat to Kingarvie, 13 July 1969, MMGLK 1998.0030.0001-0002. 
sitting on a cold toilet seat in February." ${ }^{86}$ Mowat was a prolific and lively correspondent and wrote to his son Farley and to the illustrious small craft historian John Gardner for advice on which type of boat he should build. He was strongly considering a St. Pierre dory, until he stumbled across Scott Hutcheson's old boat.

\section{Construction Characteristics}

Mowat had the boat set up in his yard and built a plastic shelter to shield it from the elements. He began rebuilding her in the summer of 1968, and the work would not be finished until 1971. Mowat quickly became obsessed with the project, and worked six hours a day, six days a week. He did all of the work himself, with occasional help from his wife Barbara. Only hand tools were used, since there was no electricity, and this project was supposed to be a sort of homage to Scott Hutcheson and the craft of traditional boat building. Mowat's enthusiasm for the project can be seen in his attention to detail, evident in the numerous letters he wrote to suppliers and fellow boat enthusiasts, and the detailed records he kept of the materials and supplies used.

In 1998 the Marine Museum of the Great Lakes commissioned detailed documentation of the boat, in preparation for its restoration. The boat historian and builder Philip Gillesse prepared a photo record of the vessel as received, which had undergone little or no alteration since it had been owned by Mowat. Gillesse carefully measured the boat, and used these data to draft the lines of the Mowat Boat, some of which are shown in figure 3. Appendix I provides specifications of the Mowat Boat, as recorded by Gillesse. The keel and keelson had been replaced with new twenty-six foot long pieces of white oak, which Mowat shaped by hand using an adze, calculating that it took him an impressive 27,000 strokes to finish the job. The stem and stern posts were also replaced with new ones of oak, and the rabbets (grooves in the posts to receive the ends of the hull planking) were cut using a chisel. Fifty-six frames or ribs were replaced with new ones of oak, ${ }^{87}$ steamed to the proper curvature and fastened to the hull planks with brass screws. The frames were $5 / 8$ " wide and were spaced about 8 " apart. Cedar boards $5 / 8$ " thick were used for the hull planking, and fifteen strakes were overlapped 1 $1 / 4$ " at the edges to form the clinker-built hull. Mowat left 80 percent of the extant hull planking intact, ${ }^{88}$ perhaps because it had already been replaced by Marion Mills and her husband.

The biggest changes that Mowat made were to the interior of the boat. He removed whatever was left of the square deckhouse and engine mounting, and constructed a small cuddy cabin forward out of plywood. The oval cockpit, visible in figure 8 , was changed to a squared shape and the side decks were widened. ${ }^{89} \mathrm{~A}$ steel centerboard was fitted in a centerboard box, and a single mast was attached to a tabernacle. In place of the gaff rig used on Scott Hutcheson's original boat, Mowat opted 
for a rig variously known as "Marconi" or "Bermudian," which had one triangular mainsail fitted with a boom and a smaller, triangular jib. This rig got its name because it could be fitted to a light, stayed mast that resembled radio or "Marconi" masts. It was used in the vicinity of Bermuda and so came to be called "Bermudian" as well. The Marconi rig selected by Angus was a wise choice, as it was easier to handle than the gaff rig, which had extra halyards to raise and lower the gaff. The Marconi rig had only a single halyard to raise and lower sail, ${ }^{90}$ and Mowat also used an inboard roller reefing system to aid in shortening sail. The sails eventually selected were a vibrant red, and created a picturesque effect when set against the black hull. As the boat neared completion in the spring of 1971 Mowat was faced with the dilemma of what to christen her. He had originally settled on Aonghas Dubh an Balquholly, which is Gaelic for "Black Angus of the Bay of Quinte," Hutcheson, to honour the original builder. In figure 11 that name is clearly visible as the boat is being

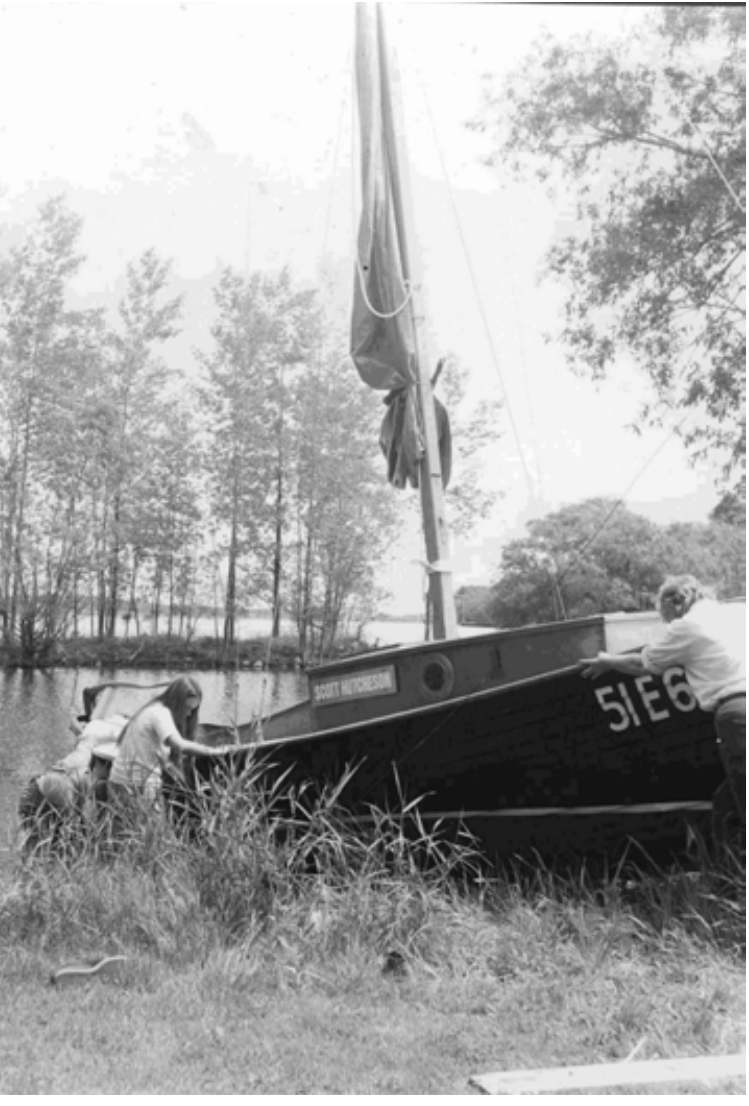

Figure 11. The Mowat Boat being launched at Northport on the Bay of Quinte in the spring of 1971. In place of the the Gaelic Aonghas Dubh Mowat decided to name the boat after her original builder. Source: MMGLK Coll. Doc. Files 1998.0030.00010002. launched into the Bay of Quinte in 1971. Mowat sailed the Scott Hutcheson out of Northport in Prince Edward County, but rarely ventured further than Trenton, although even this voyage once took him eleven hours. ${ }^{92}$ Figure 12 shows Mowat at the helm of his pride and joy. Mowat was in his late seventies by the time the boat was finished, and wisely took along younger crewmen as he occasionally suffered from "dizzy spells." 93 Despite his zest for life Mowat could not escape the hands of time forever, and passed away at the age of eighty-four in September $1977 .^{94}$

90 Charles D.White, Handbook of Sailing (New York: Thomas Y. Crowell, 1947), 14.

91 Jackson 2006, 21.

92 Gibson 1974.

93 Mowat to Hans, 17 September 1970, MMGLK 1998.0030.0001-0002.

94 "Angus Mowat Former Librarian in Trenton - Obituary," The Trentonian, 25 September 


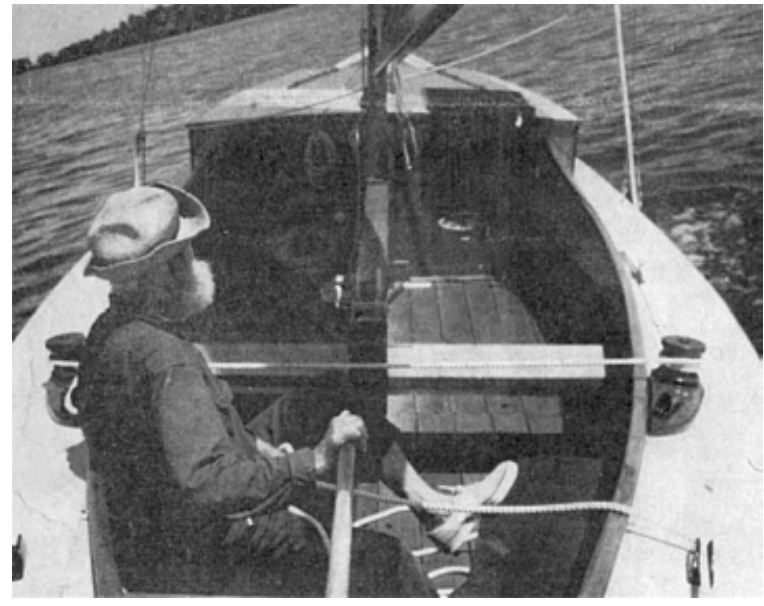

Figure 12. Angus Mowat at the tiller. He sailed out of Northport on the Bay of Quinte, and rarely ventured further than Trenton. Source: O'Connor.
No one could doubt Mowat's enthusiasm for the craftsmanship and character of Scott Hutcheson, and in fact he would announce it to any who would listen. "Anything I had to do with the boat I've regarded as a commemoration to him [Scott Hutcheson], perhaps something of him that I'm keeping alive."95 However, the scope and quality of Mowat's work has been questioned by modern small craft researchers like Gillesse, who is almost scathing in his criticism: "Mowat's workmanship is distinctly amateur, the techniques that he used are in many instances idiosyncratic, and the materials that he used are in most instances modern. The historic

value of the Mowat Boat is, therefore, very questionable." 96 The amateur workmanship Gillesse refers to includes Mowat's use of cedar butt blocks to join the ends of the hull planking, instead of proper scarf joints, as well as the use of ferrous instead of copper nails to join the edges of the planks. To make matters worse, these ferrous nails were clenched in the same direction as the grain of the wood, which greatly enhanced the decay of the wood and caused it to split along the line of fastenings. An "idiosyncratic" technique was the fastening of the frames to the strakes, where some screws were driven from the inside, and some from the outside. The proper method is to drive the screws from the outside. Modern materials include the extensive use of mahogany plywood for the cuddy cabin and stern sheets. The choice of Bermudian rig is also modern, and if Mowat's primary concern was authenticity, he should have installed a gaff rig as well as a bowsprit. Despite Mowat's condemnation of modern motor boats, he installed an outboard engine on a plank jutting out near the stern.

Still, if Mowat hadn't purchased Marion Mills's boat, it seems unlikely that it would be in a museum today, not least because the boat would have no cachet of celebrity. Researchers and builders who criticize Mowat's workmanship are doing so with the benefit of hindsight. In the late 1960s and early 1970s when Mowat was rebuilding the boat the traditional boat revival movement was still in its infancy, and wouldn't fully blossom until the later 1970s with the advent of publications like WoodenBoat. Mowat's workmanship is indeed somewhat amateur when compared to professional boatbuilders or even skilled part-time ones like Scott Hutcheson. In Mowat's defence, it should be noted that he was a man who had spent most of his working life in libraries, and thus was

1977.

95 Aleda O'Connor, "Childhood Memory Comes Alive as Boat Restored."

96 Gillesse to Cannon et al, 1 November 1998, MMGLK 1998.0030.0001-0002. 
not used to working with his hands. Perhaps the greatest affront to a modern boat researcher is Mowat's obliteration of most traces of the original 1910 boat. "With few exceptions, even where the remodeling would have allowed these replacement pieces to be exact or nearly exact copies of their originals, Mowat chose to do things his own way." ${ }^{" 97}$ This statement is certainly true, but many of the alterations Mowat made were concessions to his advanced age. The cuddy cabin allowed him a place to shelter when he had his periodic "dizzy spells," and the self-reefing Bermudian rig was easier to handle than an authentic gaff rig. Mowat had taken an old weather beaten work boat and transformed it into a gleaming yacht, but in this he was following a long tradition on the Lakes.

\section{Working Boats as Yachts on the Great Lakes}

Pleasure boating on the Great Lakes could be said to have begun with the regattas held by Governor Simcoe and his wife in the late eighteenth century. Later, British naval officers stationed at Kingston also amused themselves with regattas. These early events were fairly informal affairs; the Royal Toronto Yacht Club was founded only in $1852,{ }^{98}$ and the Kingston Yacht Club in $1896 .{ }^{99}$ Members of these clubs tended to be wealthy, and many could afford custom built yachts staffed by a professional crew. ${ }^{100}$ As the middle class expanded in the second half of the nineteenth century they sought the same kind of leisure activities enjoyed by the elite. Most could not afford large, custom-built yachts, and they turned to small craft such as skiffs and canoes, ${ }^{101}$ and converted boats for work into boats for pleasure.

The Watts family of Collingwood were always ready to diversify, and were at the forefront of the trend to build yachts from what had been working boats. In the 1870s a man named Carmichael ordered a thirty-three-foot or thirty-five-foot Watts boat with special modifications for recreational use. The forward ten feet were decked, and amenities such as sleeping berths and a stove were installed below. The heavy boilerplate centerboard employed on the fishing boats was replaced by a lighter one of wood. Apparently this pioneering boat was a success and her design was copied. ${ }^{102}$ In $1890 \mathrm{Sir}$ Edmund Walker, the banker who helped found the Art Gallery of Ontario and the Royal Ontario Museum, ordered a Collingwood skiff to use for pleasure sailing on Lake Simcoe, and called her the Nahma. She provided many happy experiences and he replaced her by another boat of the same name in 1923 that incorporated much of the ironwork from the first vessel. ${ }^{103}$ While other Collingwood skiffs fell into neglect and

97 Ibid.

98 C.H.J. Snider, Annals of the Royal Canadian Yacht Club 1852-1937(Toronto, ON: Rouss and Mann Ltd., 1937), 18.

99 Margaret Angus, "The Kingston Yacht Club," unpublished paper in Audrey E. Rushbrook Memorial Library, Marine Museum of the Great Lakes Kingston.

100 John Summers, "Forgotten Watercraft," Freshwater Vol. 5, No. 1 (1990), 8.

101 Summers 1990, 9.

102 Barry 1971, 106-107.

103 Watts and Marsh 1997, 143. 
were lost, the Nahma was treasured by a series of owners and thus survived the ravages of time to provide a first-hand example of Collingwood skiffs as yachts. She is 26 feet in length and is two-masted, with a gaff rig. Overall the differences between a Collingwood fish boat and the Nahma are minor. The latter boat is decked forward, to create a sheltered area, the stern sheets have extra seats, and the rudder is slightly deeper than those on fish boats. The Nahma continued to sail into the 1970s, and thus provides some anecdotal evidence about the sailing performance of work boats that had been converted to yachts. Lorne Joyce reports that in 1975 the Nahma was faster than many more modern boats, but couldn't tack as close to the wind, because of her older style of rig. ${ }^{104}$

The Watts boat yard closed in 1943, but their practice of building pleasure boats based on work boat designs did not. In the postwar era small craft enthusiasts like the Howard Irving Chappelle tirelessly advocated the adoption of working boats as yachts, in place of the prefabricated fiberglass boats that were becoming popular. Chapelle felt that working boats were uniquely suited for conversion to pleasure boats, as they had evolved in specific areas to meet demanding local environmental and work conditions. Wooden work boats were also relatively easy to build and maintain, and were economical alternatives to purpose-built yachts. ${ }^{105}$ Consciously or not, Angus Mowat was undoubtedly influenced by these same sentiments when he resolved to transform a decrepit old fish boat into a shiny day-sailer.

\section{The Mowat Boat as a Museum Artifact, 1989-Present}

After Angus Mowat died in 1977 his boat passed into the hands of his nephew, Andy Thomson, who donated it to the Marine Museum of the Great Lakes in 1989. It appears she had been stored outside, as standing water had caused many of the hull planks fitted by Mowat to rot, and much of the plywood was delaminated. However, the keel, stem and stern posts, and most of the frames were still in good condition. ${ }^{106}$

\section{Issues of Preservation Philosophy}

There were several options available to the museum, each with its own advocates and naysayers in the classic boat and maritime museum communities. One school of thought suggests that old boats should be left in an "as-received" condition, to illustrate the wear and tear they underwent, and so provide an accurate picture of what they might have looked like in use. This is the philosophy of the Lake Champlain Maritime Museum, where boats are given only a minimal amount of cleaning before being put on display. Any work done on a boat would be purely conservation, that is to stabilize the object while altering its original appearance as little as possible. ${ }^{107}$ An option related to the conservation philosophy is to record carefully the original boat and then use the

\footnotetext{
104 Joyce 1997, 12.

105 Chapelle 1951, 3-4.

106 Jonathan Watson to MMGLK Board of Directors and Executive Director, 26 June 2003, MMGLK 1998.0030.0001-0002.

107 Hallie Bond, "What is Museum Quality?" WoodenBoat 144 (1998), 84, 87.
} 
measurements to build an identical copy, that is replication. Building and sailing replicas allows skills that are on the verge of being lost to be passed on to youth and other interested individuals. This is the approach championed by John Gardner of the Mystic Seaport Museum, ${ }^{108}$ but one that requires considerable resources.

A third option is restoration, which can be defined as "returning an object to a former and sound condition." ${ }^{\prime 109}$ This was the route eventually chosen by the staff of the Marine Museum of the Great Lakes after considerable reflection. The Bay of Quinte fishing boat as built in 1910 by Scott Hutcheson would be a rare and thus historically significant type. However, rebuilding by Marion Mills and Angus Mowat had all but destroyed any traces of the original boat. It was judged too difficult to restore the boat to the Scott Hutcheson period of ownership, as the only evidence to work with was a few faded photographs. Had this restoration been attempted, a large amount of speculation and hence historical ambiguity would have come into play. Since the original structure of the boat had already been seriously compromised, it was decided that there was little reason to leave the boat "as-is" and apply only minimal conservation treatment. Instead, it was decided to restore the boat to the Angus Mowat period, as this would simultaneously stabilize and refurbish the deteriorating structure, while allowing volunteers to learn the art of wooden boat building.

\section{Restoration to the Angus Mowat Period}

Although museum staff had grappled with the thorny issues of preservation philosophy soon after the boat's arrival in 1989, it was not until 2003 that restoration work got underway in earnest. The Marine Museum was diligent in their preparations, and followed the tenets of good restoration policy by first having the boat fully documented, with photos as well as line drawings. A team of interested and enthusiastic volunteers came together: Gordon Bales, Danny Brooks, Ivan DeRome, Gerald Gamble, and Ron Lees, under the leadership of Peter Cobbett. Some of the volunteers had helped restore the steam yacht Phoebe and most were avid sailors, but beyond that they had little experience building wooden boats. A restoration plan was drawn up and work space allocated at the rear of the Marine Museum. Beginning in the spring of 2003 the volunteer crew worked on the boat two days a week until winter squalls off nearby Lake Ontario signalled the end of the season. Most of the hull planking was replaced with new cedar planks $5 / 8$-inches thick. The planks were made pliable in a homemade steambox, or sometimes immersed in the nearby lake water for several days. During the frequent humid spells that characterize Kingston summers, boards would absorb enough moisture to be easily bent to shape without added steaming. ${ }^{110}$ Mowat's leaky butt blocks were

108 John Gardner, "New Directions in Small Craft Collection and Preservation," in Wooden Shipbuilding \& Small Craft Preservation (Washington: National Trust for Historic Preservation, 1976), 22.

109 Richard V. Palmer, "The Philosophical Implications of Restoration versus Replication,” in Wooden Shipbuilding \& Small Craft Preservation (Washington: National Trust for Historic Preservation, 1969), 27.

110 Jackson 2006, 20. 


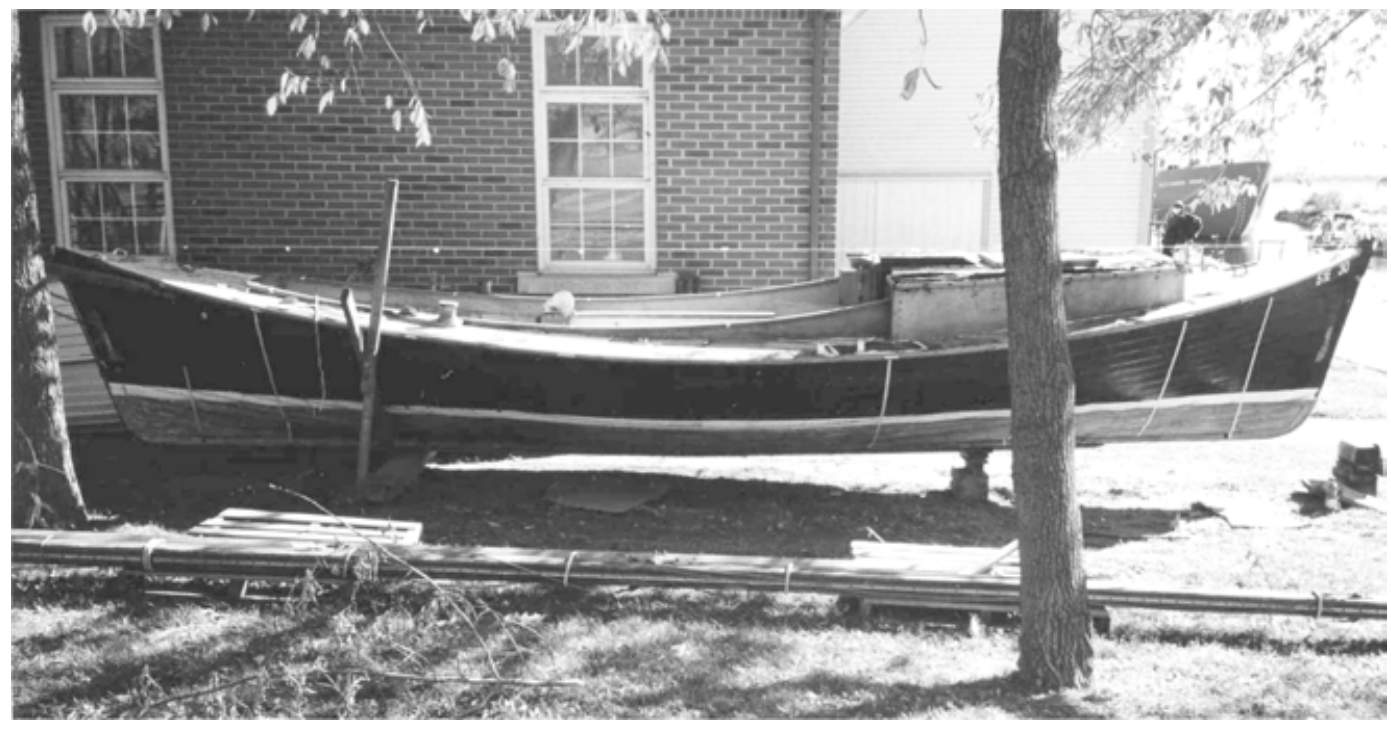

Figure 13. The Mowat Boat as she appeared prior to restoration at the Marine Museum of the Great Lakes, in Kingston, Ontario. Source: MMGLK Coll. Doc. Files 1998.0030.0001-0002.

replaced with proper four-inch scarf joints. Many parts of the boat were found to be in good shape and were retained, with a few cosmetic touches. The keel, keelson, and stem and stern posts were left intact, while the steel centerboard and ballast keel were sandblasted and then reinstalled. The delaminated mahogany plywood that formed the cuddy cabin, decking, and stern sheets was removed and replaced with marine plywood. Most of the exotic mahogany wood that Mowat had used in components like the cabin trim and corner posts was replaced with oak, although the mahogany tabernacle was found to be sound and was retained. The rig will be the same as that used by Angus, with red sails in a Bermudian configuration equipped with roller-reefers. The hull was painted black above the waterline and red below, while the interior is mostly gray. The cabin exterior, trim, and spars now glisten with enough fresh varnish to bring a lump to Angus Mowat's throat, could he see her.

\section{Conclusion}

At the time of writing, in the last weeks of 2007, the Mowat Boat is complete except for a few odds and ends. She rests quietly, and except for the odd incursion by local vagabonds, safely in her plastic shelter behind the Marine Museum. It is planned to launch her in the spring of 2008 with suitable fanfare generated by Farley Mowat, who is now older than his father was when he built the boat. The Mowat Boat will be an invaluable component of an upcoming exhibit on small watercraft, and the stories she can tell will help educate the public about small watercraft on Lake Ontario. It is also hoped to conduct sea trials with the Mowat Boat, to obtain empirical data on how she performs under different positions of ballast and sail, and weather conditions. This type of data obtained from Great Lakes small craft is comparatively rare, and will add new knowledge to the field. 
In the century since she was first shaped by the hands of a fisherman on the Bay of Quinte the Mowat Boat has undergone many different incarnations, each bearing witness to the development of watercraft on the Great Lakes, as well as wider historical and socio-economic trends. In her original form as a clinker-built fishing sloop she incorporated many aspects of traditional wooden boat design embodied in the Mackinaw boats and Collingwood skiffs of the latter nineteenth century. As a motorized fishing boat in the 1960s the Mowat Boat reflected new technological developments and economic realities. Her rebuilding by Angus Mowat was part of a larger movement that eschewed modern boats in favour of working craft, and emphasized restoration and a spirit of selfreliance. Finally, as a museum piece restored by volunteers, the Mowat Boat illustrates the increasing value being placed on local maritime heritage as well as the enduring interest this subject holds for many. Hopefully this rugged little boat will continue to inspire and educate for generations to come.

\section{Postscript}

In the early summer of 2008 a crane at a local dockyard gently returned the Mowat Boat to the waters of Lake Ontario, with minimal fanfare. Over the next several months Andy Soper, a sailmaker and professional sailor, tested the sailing qualities of the craft with the assistance of the restoration volunteers. A series of a half dozen excursions produced some interesting data. The Marconi rig favored by Angus Mowat proved to be slightly undersized and imbalanced, a minor issue remedied with the addition of extra canvas on the headstay. While the boat does not sail as well to windward as modern craft, it compares well with older types, and reached an impressive top speed of 12 knots. It is hoped to make these short daytrips an annual event, with the goal of combining informal research into the performance of the vessel with public relations events. In the meantime the Mowat Boat restoration crew refurbished a 14-foot jolly boat, and are on the lookout for their next challenge.

The author gratefully acknowledges the inspiration and support of Maurice D. Smith, curator emeritus at the Marine Museum of the Great Lakes. This paper never would have been written without the hard work of the entire Mowat Boat restoration team, consisting of Gordon Bales, Danny Brooks, Peter Cobbett, Ivan DeRome, Gerard Gamble and Ron Lees. The author also wishes to extend his sincere thanks to the rest of the staff and volunteers at the Marine Museum of the Great Lakes. 